الاغتراب فى قصة "آدم" لزهر ا خوش نظر دراسة تحليلية

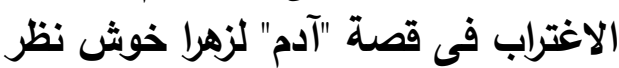

\section{دراسة تحليلية}

د /هاله حسن محمد

المدرس بقسم اللغة الفارسية وآدابها

كلية الآداب - جامعة المنوفية

تمهيد

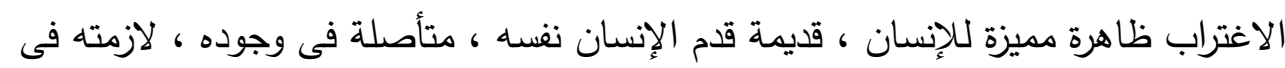

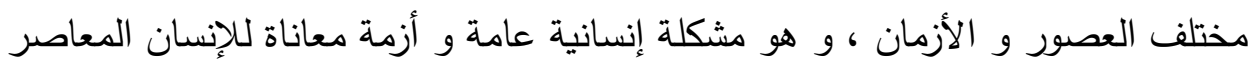

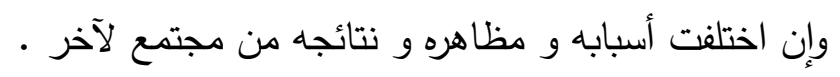
و يعد مفهوم الاغتراب من أكثر المفاهيم إثارة للجدل و ولانيا لاختلاف الآراء بين المفكرين والفلاسفة ، فهو من المفاهيم التى من الصعب إعطاء حل قاطع فيها و و و تحديد معنى شامل لها

مقدمة تعريف الاغتراب

الاغتراب لغةً : فى اللغة العربية نقول "غرب" أى ذهب و ت تنحى عنه الناس و التغرب يعنى

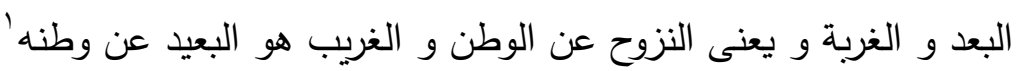

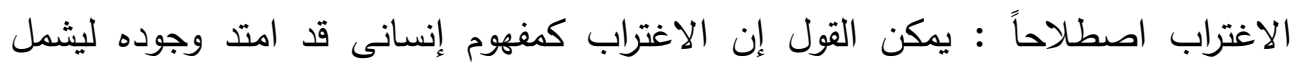

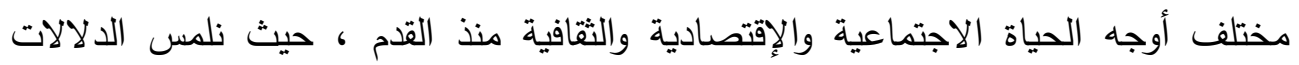
الأولية لمفهوم الاغتراب فى أعمال " سقراط" و " أفلاطون " و" أرسطو " و كتابات القديس " أوغسطين" الأية

' - جمال الدين ابن منظور بن مكرم الأنصارى : لسان العرب ، مجلد · ل1 ، الطبعة الأولى ، دار صبح ، لبنان ،

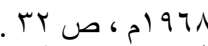

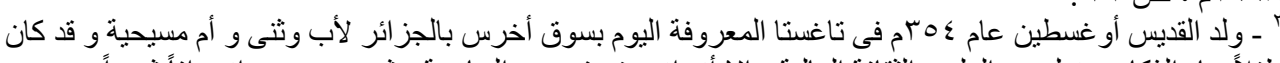

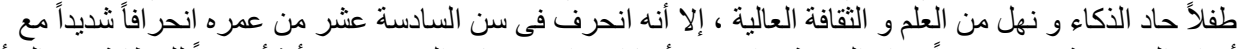

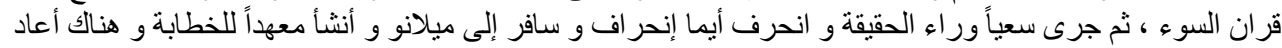

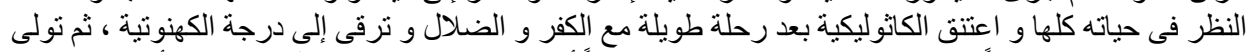

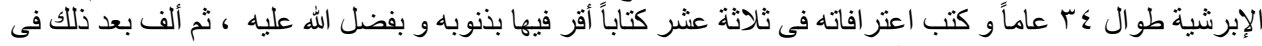

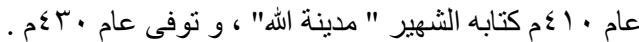

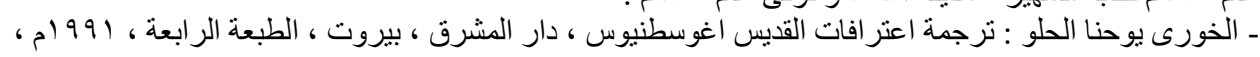


وقد ازداد التتوع فى استخدام مصطلح الاغتراب نتيجة لاختلاف الاتجاهات الفلسفية - والتى تعد جذوره الأولية - و السيكولوجية ( النفسية) والسوسيولوجية ( الاجتماعية) فى استخدام هذا المفهوم ، إلا أن معظم الدراسات تُجمع على أن "هيجل"؛ هو أول من جاء بمعنى منظم

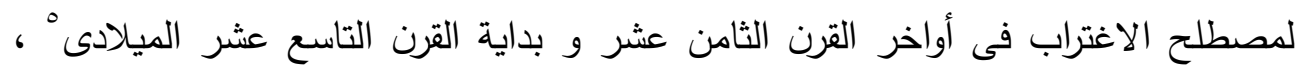
فهو يعتبر أن الاغتراب يعنى انفصال الذات الإنسانية ككيان روحى عن وجوده ككائن

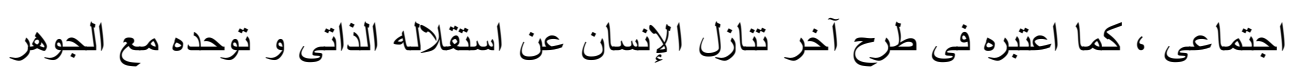

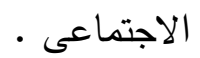

' ـ قيس النورى : الاغتر اب اصطلاحاً مفهوماً و واقعاً ، الكويت ، مجلة عالم الفكر ، المجلد 19 ، العدد ا ، عـ9 ام

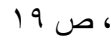

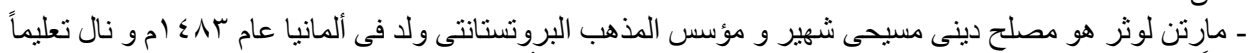

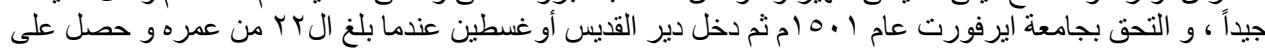

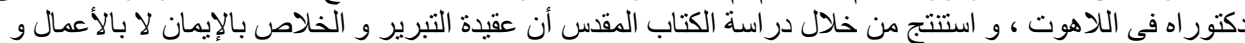

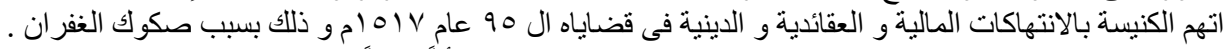

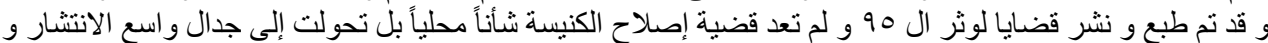

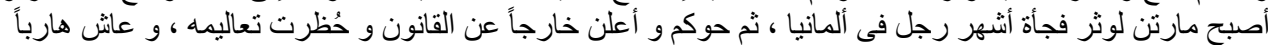

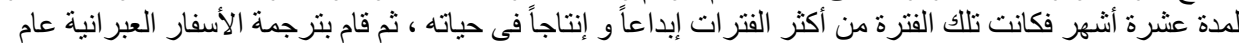

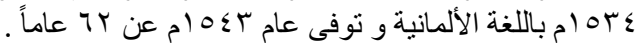

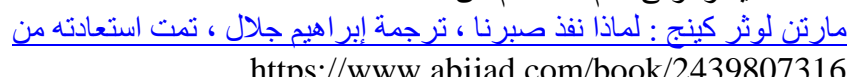

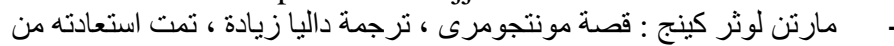
http://daliaziada.blogspot.com.eg/2008/03/blog-post_24.html

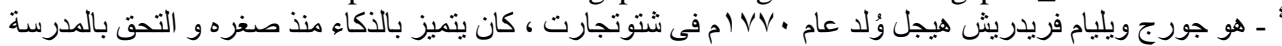

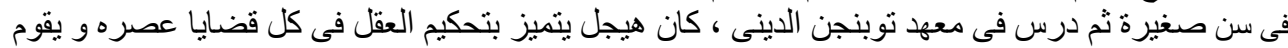

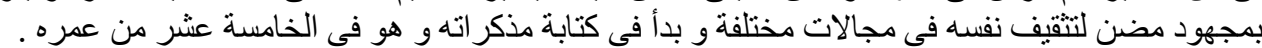

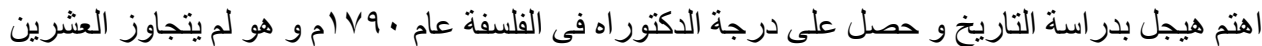

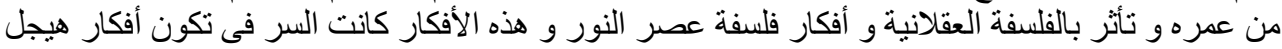

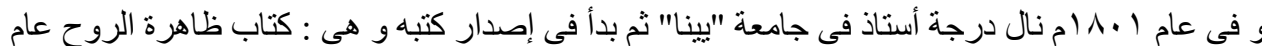

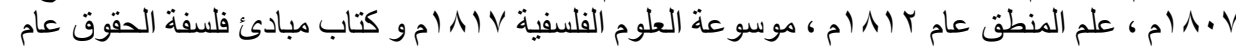

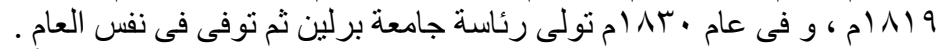

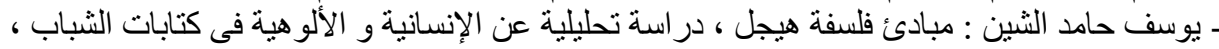

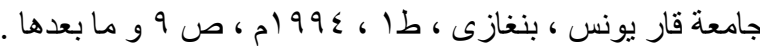

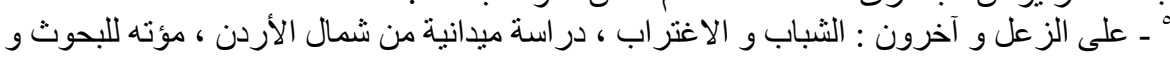

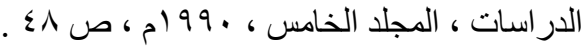

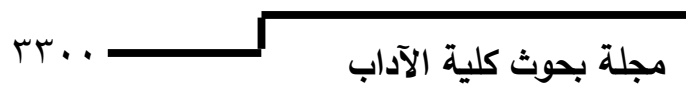




\section{الاغتراب فى قصة "آدم" لزهرا خوش نظر دراسة تحليلية}

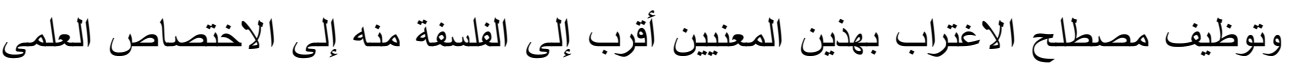
، نظراً إلى أن "هيجل" استخدمه فى بدايات الاهتمام به كمؤشر للبحث ' . وقد ميز "هيجل " بين أنواع مختلفة من الاغتراب ، كاغتراب الشخصية و اغتراب النظم الاجتماعية و الثقافية ، و وصف الإنسان المغترب كالإنسان الذى يعيش فى عالم الأموات

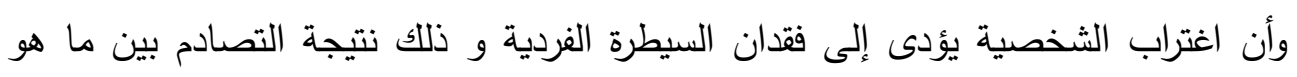

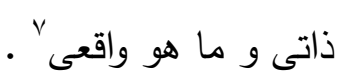
أما " روسو" دفيرى أن الحضارة سلبت الإنسان ذاته و وأفقدته الذات الاجتماعية التى أنشأها و كونها و أصبح تابعاً لها و بذللك فقد الإنسان التتاغم العضوى بين ما ينبغى أن يكون

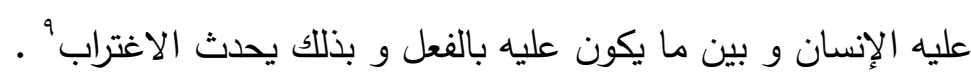

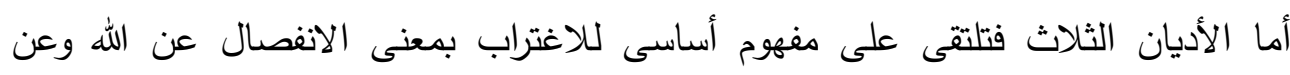

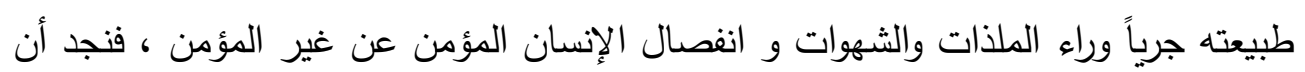

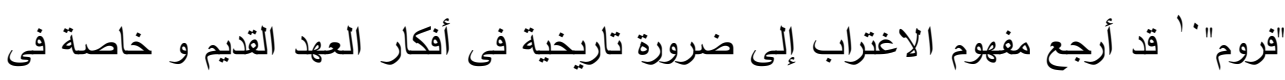

، ـ عبد اللطيف محمد خليفة : دراسات فى سيكولوجية الاغتر اب ، دار غريب للطباعة و النشر و التوزيع ،

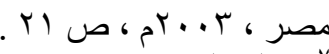

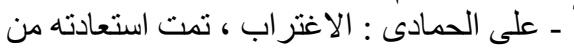

http://montada.echoroukonline.com/showthread.php?t=229620

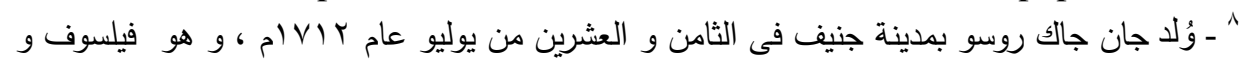

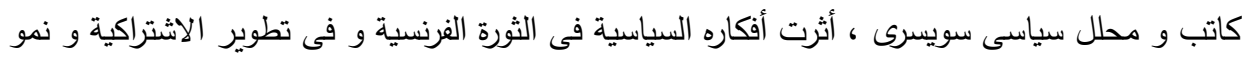

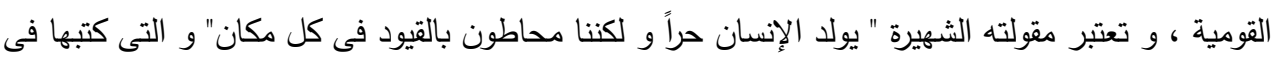
أهم مؤلفاته ( العقد الاجتماعى ) ، هى أفضل تعبير عن أفكاره الثورية و ربما الدنطرفة ، و من من أعماله :

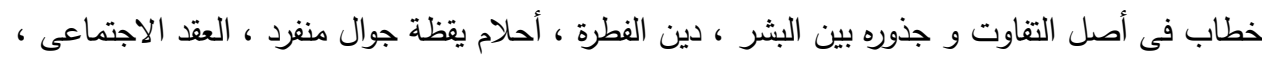

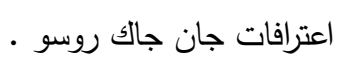

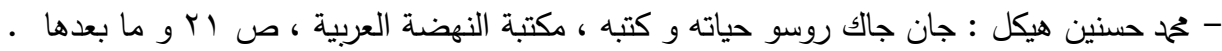

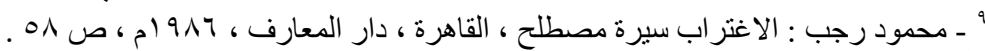

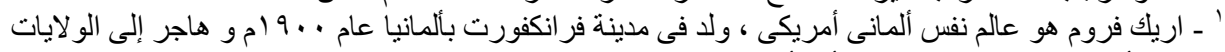

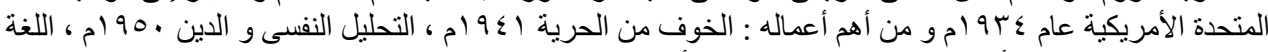

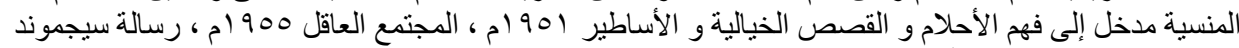

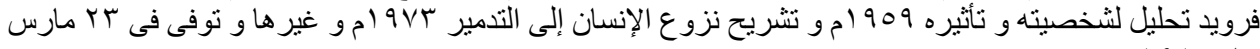


سفر التكوين منذ بداية الخلق فقد أثار إلى أن الاغتراب يحدث بين الله و الإنسان نتيجة سقوط الإنسان فى الخطيئة أو الوقوع فى المعصية و لذلك أرجع اغتراب الإنسان إلى اغترابه

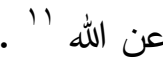

أما الاغتراب فى الإسلام فقد تمثل فى أن الإنسان بعد ما كان واحداً مع الله صار منفصلاً عنه أى أن الوحدة التى كانت تتمتع بها روح الإنسان فى وجوده الأصلى الأول قد انفصمت النقال

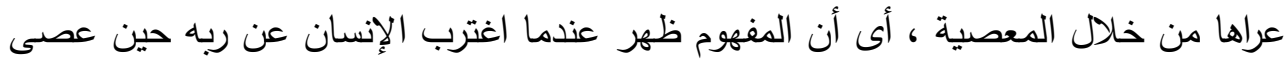

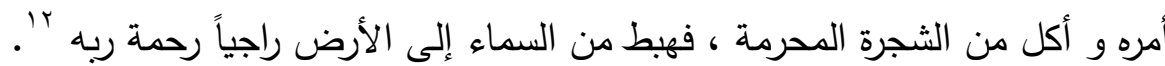

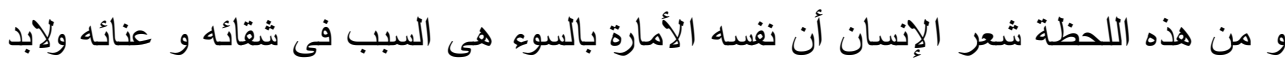
من مجاهدتها و محاربتها من أجل الترقى مرة أخرى للوصول إلى المصدر النقى الصافى الأى هبطت منه بالتخلص من سجن المادة . و يشار للاغتراب أيضاً بالمعنى الإسلامى إلى ذلك الإنسان الذى ييتعد عن الحياة الاجتماعية و مغرياتها بطرق إيجابية و سلبية فيقهر السلطتين معاً سلطة الحكم الجائرة

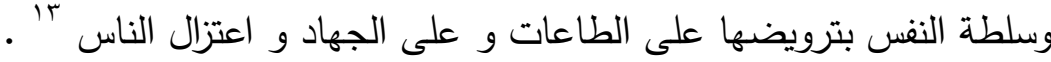
كما كان للتصوف دور كبير فى انتشار مفهوم الاغتراب فقد كان هو الأرض الخصبة التى نما فيها الاغتراب ، فاستخدمه الصوفية بمعانيه المختلفة و عايشوه تجربة وجدانية و وجودية ذات أبعاد دينية تبدأ بخروج الإنسان من الجنة و هبوطه إلى الأرض ، و هذا ما أثار إليه ابن العربى الذى يرى أن الاغتراب يعنى انفصال الإنسان عن الله و يعبر عن هذه الفكرة بقصة آدم و هبوطه من الجنة إلى الأرض ، و يقول إنى إنى أول غربة اغتربناها وجوداً حسياً عن وطننا غربتنا عن وطن القبضة عند الإثهاد بالربوبية لله علينا ، ثم عمرنا بطون الأمهات فكانت الأرحام وطننا فاغتربنا عنها بالولادةء

ـ اريك فروم : الاغتر اب ، ترجمة حسن حماد ، المؤسسة الجامعية للدر اسات و النشر و التوزيع ، بيروت ، 990 ام

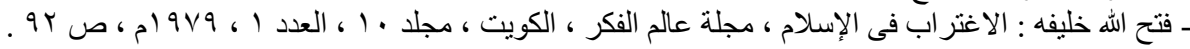

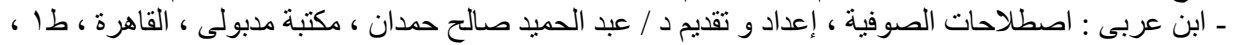

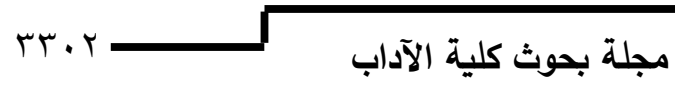


الاغتراب فى قصة "آدم" لزهر ا خوش نظر دراسة تحليلية

$$
\text { المفهوم الوجودى للاغتراب }
$$

لقد تتاولت الوجودية عدة موضوعات تتصل عميقاً بتجارب الاغتراب ، كمشاعر التعلق بحق الاختيار و ما يرافقه من أحاسيس المسؤلية و القلق و العبث و الغربة و العجز و اللاانتماء ، و رسمت صورة للإنسان الحديث على أنه فى الوجود كمسافر فوق بحر لا خريطة له

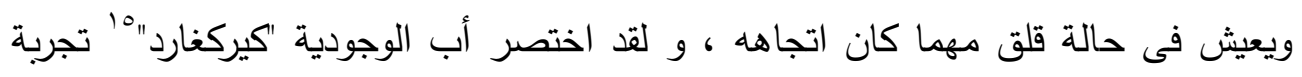
هذا البحث المستمر على الشكل التالى :-

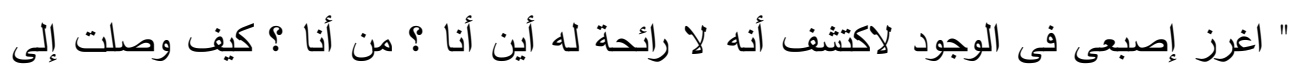
هنا ؟ ما هو الشئ الذى يسمى العالم ؟ من هو الذى ضللنى و تركنى هنا ؟ كيف بدأت

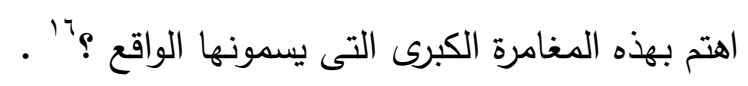
و بعد دخوله الاستخدام العلمى وردت لله عدة تعاريف أهمها و أشملها : هو اضطراب نفسى يعبر عن اغتراب الذات عن هويتها و بعدها عن الواقع و انفصالها عن

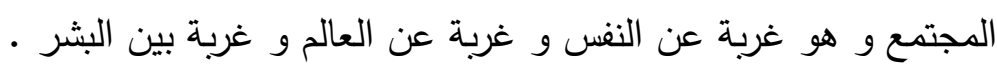

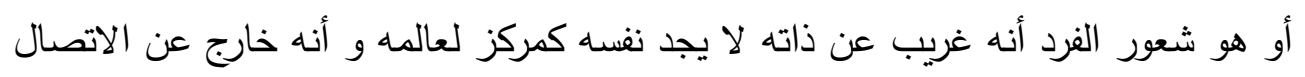

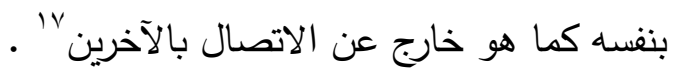

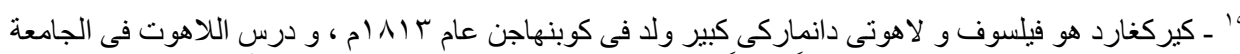

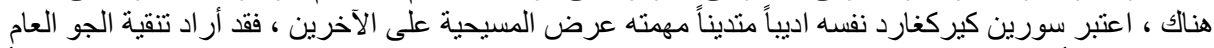

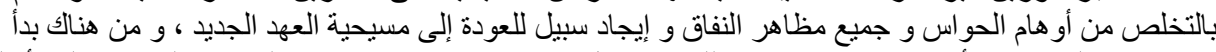

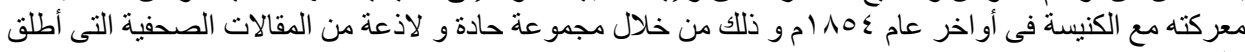

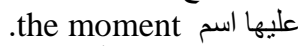

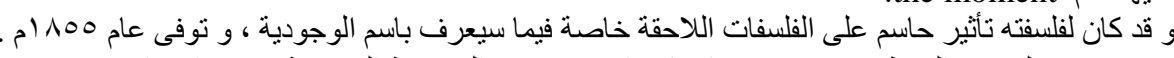

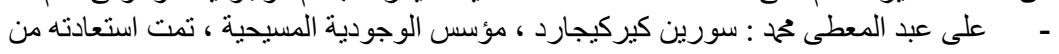
https://www.goodreads.com/book/show/28780154

17 - حليم بركات : الاغتر اب فى الثقافة العربية ، متاهات الإنسان بين الحلم و الواقع ، مركز دراسات الوحدة العربية ،

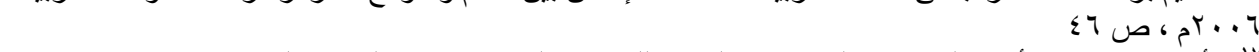

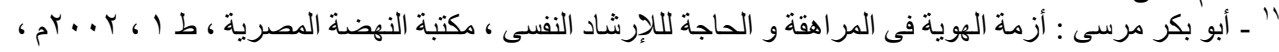


و توضح " هورنى" لهى أن الاغتراب يعبر عما يعانيه الفرد من انفصال عن ذاته ، حيث ينفصل الفرد عن مشاعره الخاصة و رغباته و معتقداته و هو فقدان الإحساس بالوجود - الفعال 19 أى أنه هو الحالة التى يتعرض فيها الإنسان إلى الضعف و العجز و الإنهيار فى شخصيته

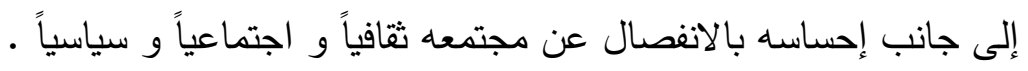

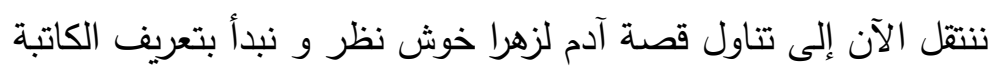

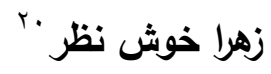

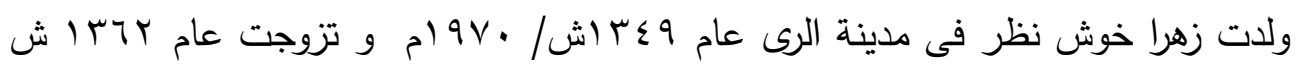

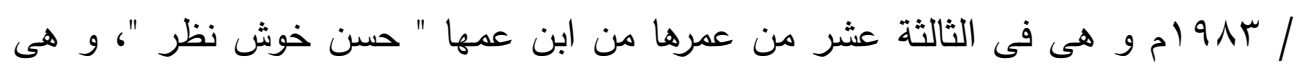

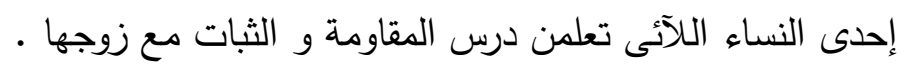

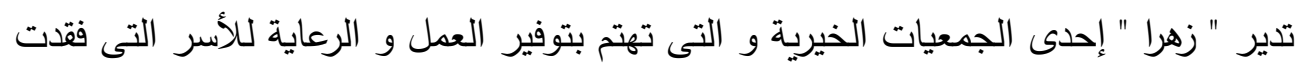

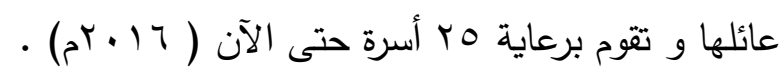

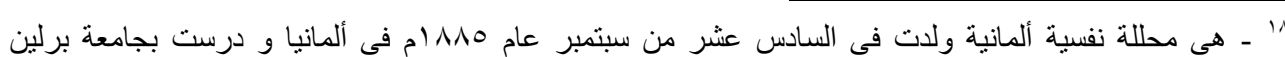

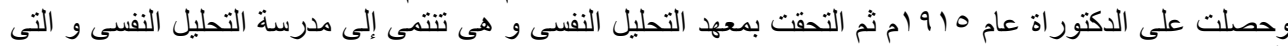
تأثرت بشكل كبير بفرويد .

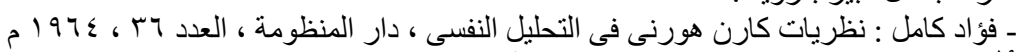

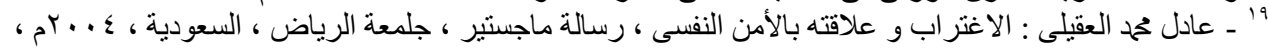
ص .

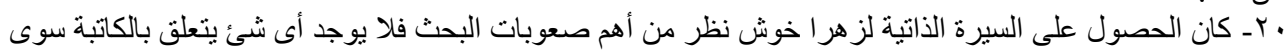

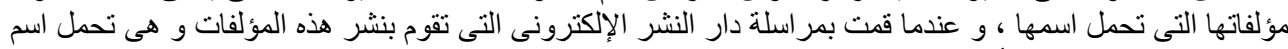

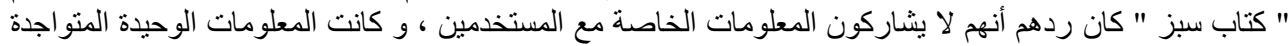

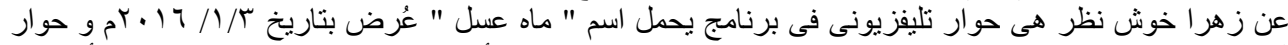

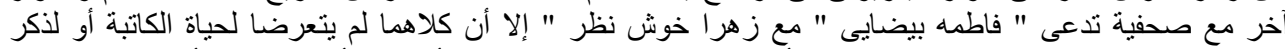

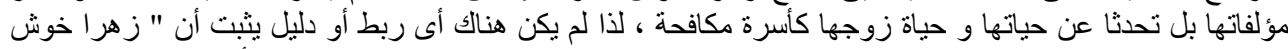

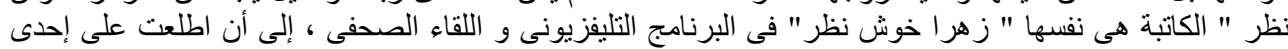

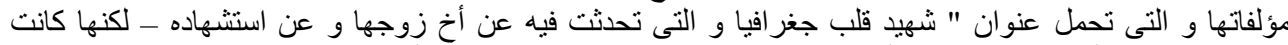

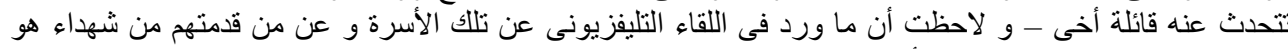

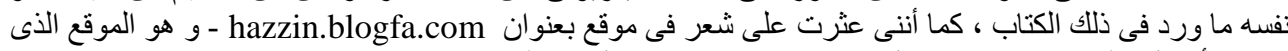

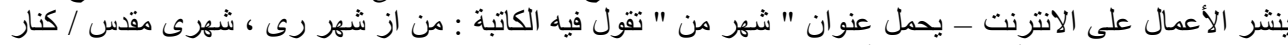

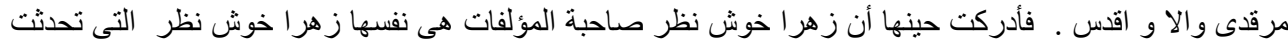

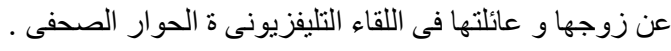

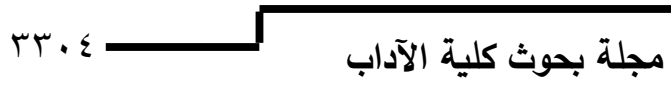




\section{الاغتراب فى قصة "آدم" لزهرا خوش نظر دراسة تحليلية}

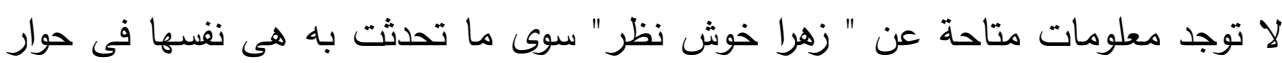

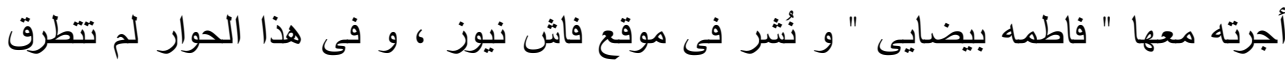

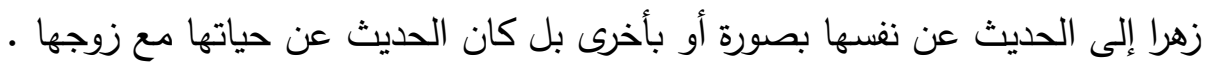

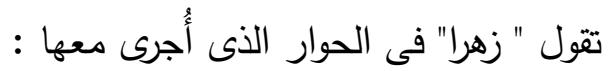

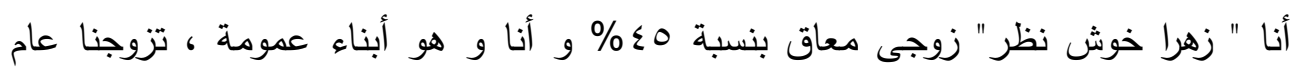

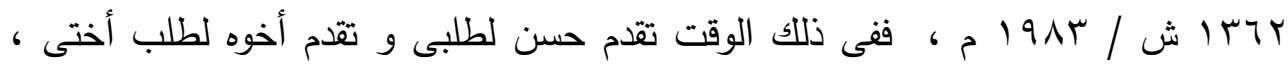

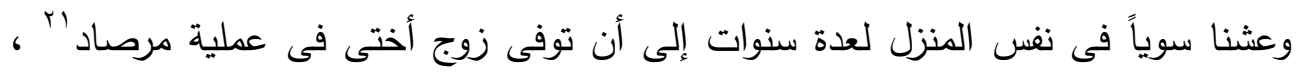

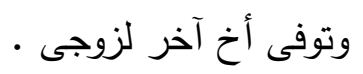

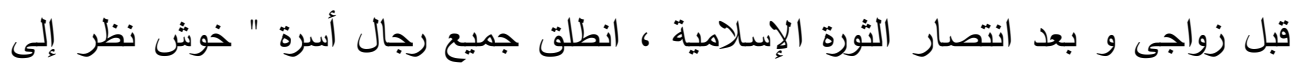

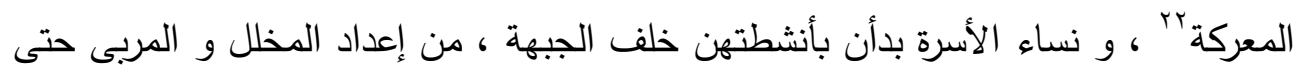

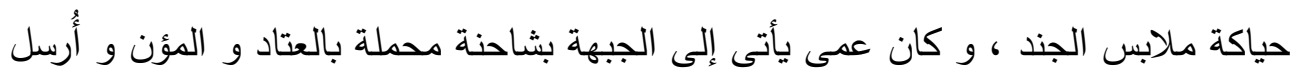

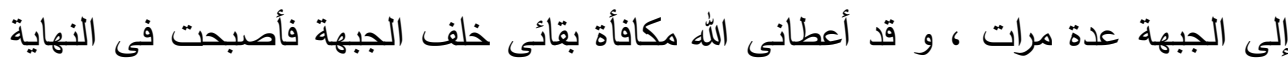

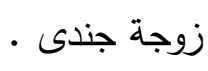

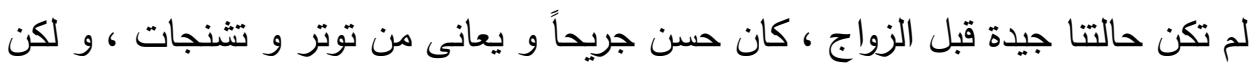

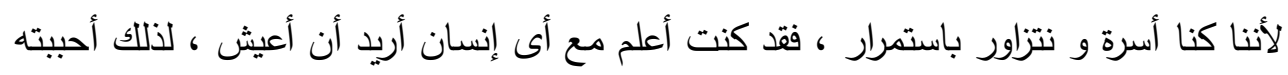

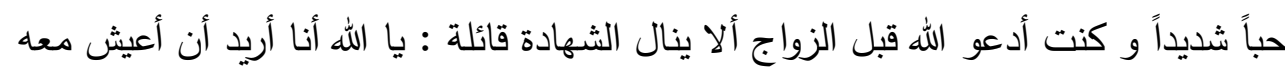

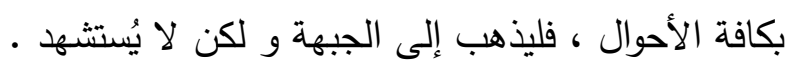

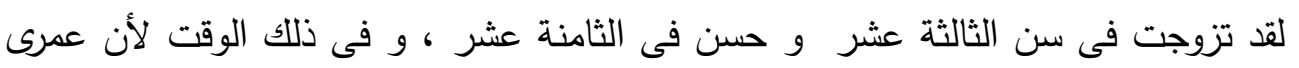

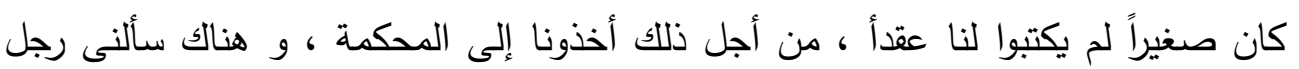

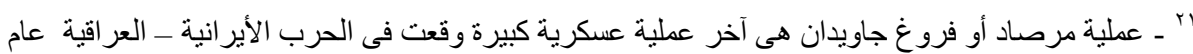

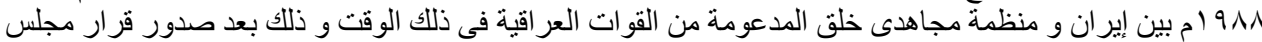

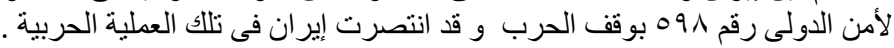

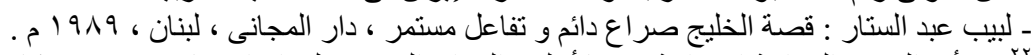

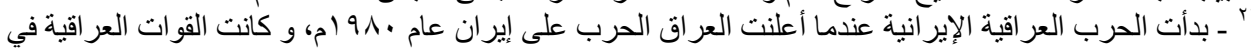

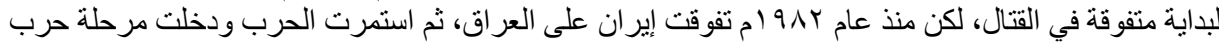

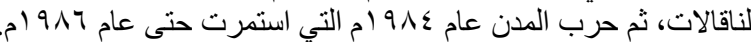

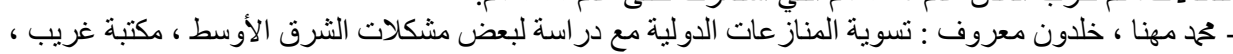

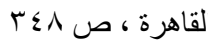


دين هل والدك يزوجك قسراً أم أنك ترغبين فى الزواج ، فقلت نعم أنا أرغب فى الزواج ،

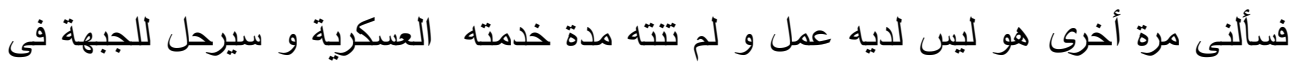
أى وقت ، فهل تريدين الزواج منه ؟ قلت نعم لأننى أحبه . فى إحدى العمليات أصابت شظايا خصر حسن و لازم الفراش مدة شهر فى المستشفى ، و و قال الطبيب من المحتمل ألا يستطيع السير و سيلازم الكرسى المتحرك ، هنالك دعوت الله لهات

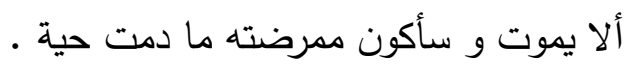

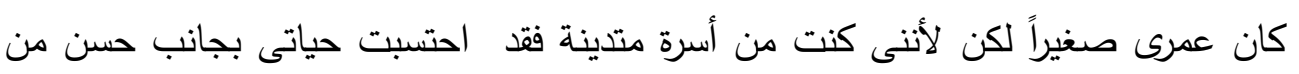
المقدسات و قد كنت فى اشتياق للزواج من حسن إلى حد أننى قلت نعم قبل أن يتم الإمام خطبته أثناء عقد القران ، فقال لى انتظرى يا ابنتى حتى تمام انتهاء الخطبة .

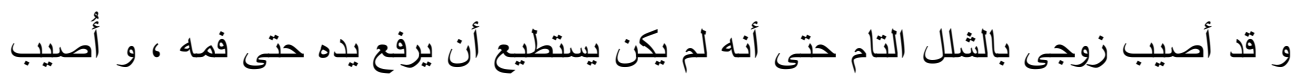

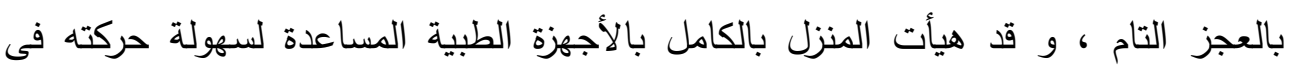
المنزل ، و الآن يستطيع حسن أن يتحدث و أن يتتاول طعامه بنفسه و أن يجلس بمفرده لهاه

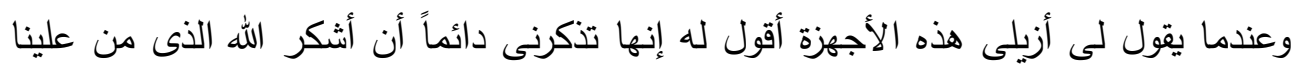
• بالشفاء لقد مرت أول خمسة عشر عاماً من زواجنا بصعوبة فعندما كان الهواء يغلق باب الغرفة أو عندما كان الأطفال يلعبون و يصيحون أو كان يسمع صوت جرس الباب و هو نائم كان يصاب بالتشنجات و لم يكن حتى عشرة من الرجال يستطيعون السيطرة عليه و كنت أقوم أنا و أطفالى و أطفال أخيه الشهيد برعايته حتى يأتى أخاه و إخوتى إلى المنزل فئس فكان الأطفال يضعون وسادة على صدره و يستلقون عليه و كنت أمسك بيديه بشدة و ذلك حتى دئى

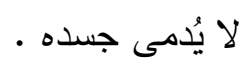
كانت الأحداث التى مررت بها تذكرنى دائماً بوجود الله و تقربنى أكثر إليه ، إن الصعوبات التى مررت بها فى حياتى مع حسن كانت لها حلاوة خاصة فعندما كانت ثيابه تتسخ كالأطفال و أشعر بضيقه من هذا الوضع ، كنت أمطره بمئات من القبلات و أقول له لا لا تضطرب و أسعى بمرح و سعادة أن ينسى هذا الأمر .

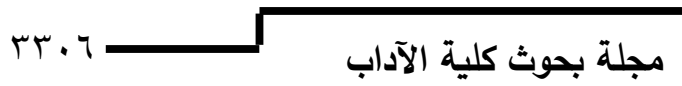




\section{الاغتراب فى قصة "آدم" لزهر ا خوش نظر دراسة تحليلية}

لقد كنت أتواجد دائماً بجوار حسن و عندما كان يأتى ضيف و يقول لى أن أحمله إلى غرفة أخرى كنت أقول له أنا أحب أن أكون بجواره و هو يحب أن يكون بجوارى من أراد أن يأتى فليأت و من لم يرد فلا يأتى أنا أدين بكل شئ فى حياتى ل زوجى حسن فقد كبرت بجواره ،

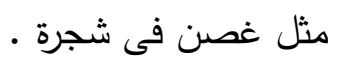

لقد عشت بجوار حسن لحظات سعيدة و لحظات قاسية إلا أن أصعب لحظات حياتى كانت عندما يدخل لغرفة العمليات ، كنا نصبح كليلى و المجنون و عندما كان يخرج من غرفة

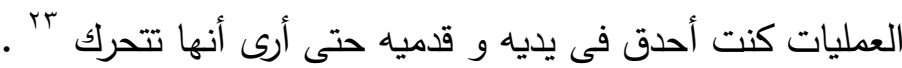
فى عام • • ا ش / / 1991 م قامت زهرا بتأسيس جمعية خيرية تقوم بتجهيز احتياجات المدارس و لوازم العيد و تجهيز الأطعمة للأسر المحتاجة ، و و بعد أن كانت الجمعية تعتمد

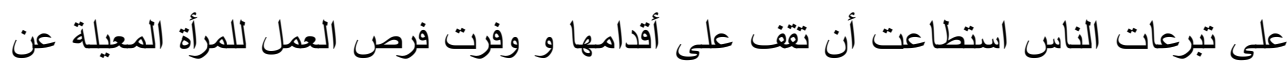
طريق بعض الأعمال البسيطة كتصنيع الخضروات المجففة و إنتاج المجدات ، فكانت النساء تحضرن إلى الجمعية منذ الصباح الباكر حتى بعد الظهر ، كما كانت الجمعية توفر لهن وجبة الغذاء و قد ساعد المسؤلون الجمعية و قاموا بتوفير مكان لها فى صالات إحدى لهى المعارض بسبب اتساع أعمال الجمعية . و تقول " زهرا" أن زوجها حسن كان هو المشجع الرئيسى لها و كان يقول لها : عندما كنت عروس جديدة كنت أتركلك بمفردك و أذهب للجبهة و الآن يجب أن أتحمل القليل من الوحدة أنها

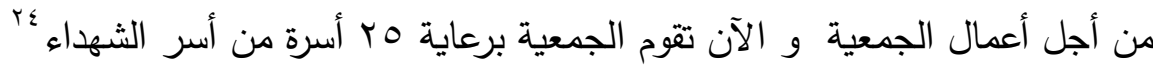
مؤلفات زهرا خوش نظر توجد لزهرا خوش نظر العديد من المؤلفات ذات الطابع الدينى و المذهبى من بينها : 1- سلام بر حضرت عشق جواد الأئمة عليه السلام r- سلام بر شهيد غريب عشق امام حسن عسكرى عليه السلام r- تا خدا فاصله اي نيست 


$$
\begin{aligned}
& \text { ع- سلام بر حضرت باران } \\
& \text { 0- مظلوميت سبز عشق }
\end{aligned}
$$

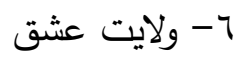

$$
\begin{aligned}
& \text { - V تجربيات نزديك به مرك } \\
& \text { 1- از واقعه ایى تو را خبر خواهم كرد } \\
& 9 \text { - عشق بوى مهربانى مى دهد ( آشنايى با سوره ایى الرحمن ) } \\
& \text {. } 1 \text { - - و خدايى كه همين نزديكى است } \\
& 11 \text { - شهيد قلب جغرافيا } \\
& \text { r r س سلام بر بانوى نور و آب و آيئنه حضرت زهرا سلام الله عليها }
\end{aligned}
$$

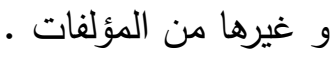

قصة آدم لزهرا خوش نظر

إن مسألة خلق الإنسان تمثل أحد أهم الأسئلة الوجودية الثلاث التى طرحها و ما زال يطرحها الإنسان على نفسه فى كل زمان و مكان و هى : من أين جاء ؟ لماذا هو موجود ؟

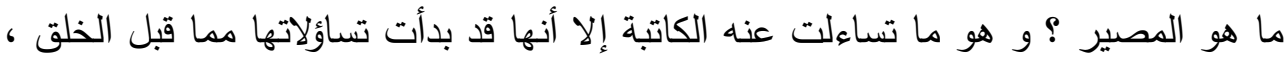
عن بداية قصة آدم و عن وسوسة الثيطان له و هو عن المعصية التى وقع فيها ، فبدأت القصة قائلة : كان يا ما كان لم يكن هناك أحد سوى الله

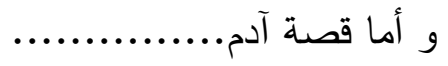
حقاً من أين بدأت قصة آدم ؟ آدم ؟ أمن الأرض ؟ عن إن بن أم من السماء ؟ الأبن

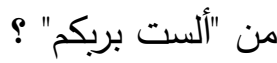

ro ـ حزين خوش نظر : داونلود كتابهاى زهرا خوش نظر ، تمت استعادته من http://ketabesabz.com/authors/2251

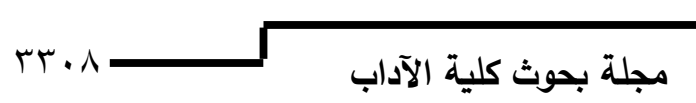


الاغتراب فى قصة "آدم" لزهر ا خوش نظر دراسة تحليلية

$$
\begin{aligned}
& \text { أم من " قالوا بلى " ؟ } \\
& \text { من كان ؟ أم من لم يكن ؟ بـ }
\end{aligned}
$$

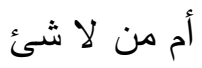

$$
\begin{aligned}
& \text { مِن لم يكن هنالك أحد سوى الله } \\
& \text { مِن "علم آدم الأسماء كلها" ؟ } \\
& \text { أم من سجود الملائكة للإنسان ؟ } \\
& \text { الإنسان الذى سجدت له الملائكة . } \\
& \text { الإنسان الذى علمه الله . }
\end{aligned}
$$

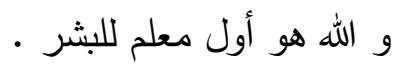

و هذا العلم أياً ما كان هو ما جعل الملائكة تسجد لآدم

$$
\text { و و لكن ليست تقدمت الأرض عذه حتى السماء الآن قصة آدم }
$$$$
\text { ليست كل القصة }
$$$$
\text { إذن ماذا كانت قصة آدم ؟ }
$$$$
\text { من أين بدأت ؟ مادات }
$$

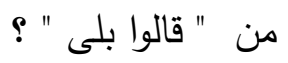

من المعرفة الفطرية ؟ من بان

من العشق الأزلى ؟ من العطرده

من الاعتراف الصريح و القاطع برب الوجود ؟

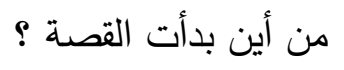

ذللك العشق الأزلى و الأبدى لعلى عليه السلام الذى قال :

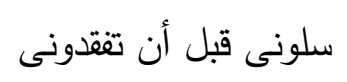

قد قال : لو لم تكن تعلم من أين أتيت ، لن ترغب فى فهم إلى أين سوف تذهب أنى

$$
\begin{aligned}
& \text { أريد أن أتتبع قصتى لَّى } \\
& \text { قصة آدم ، قصتى . }
\end{aligned}
$$


أريد أن أعلم ماذا كانت قصتى ؟

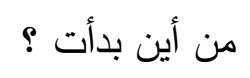

من إبليس الذى لم يكن مهيئًا ليسجد لغير الله ؟

من الثيطان حاجب الحضرة الإلهية ؟

الحضرة الإلهية التى لم يصلها أى شخص سوى المخلصين

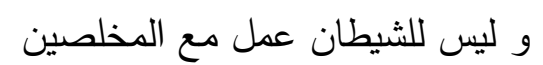
قصةُ أياً ما كانت ، ظلت وراء حجاب الغئ الغيرة و الليلة لا أدرى لماذا اتدخل فى أمور الثيطان ؟ و هو الذى تدخل فى أمورنا عمراً

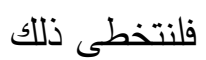
و هذه إلى الآن ليست بداية قصة آدم و لكن قصة آدم و أحزانها بدأت من تفاحة من الشجرة المحرمة . من التفاحة التى لم تستطع معدة الإنسان إلى الآن أن تهضمها ـ التحرة من القصح الذى لم يكن له له من التفاحة التى قال عنها "فيكتور هوجو" : ليت أنويتها خنقت عنق الإنسان قصة آدم هى قصة تفاحة حمراء و بيضاء و لامعة المانة مثل ذلك اللمعان الذى ألقى الوسوسة فى قلبه و تلك الرغبة التى جعلت قلبه يرتعش و ليس و و يده ريما هي قصة سنبلة ذهبية " " يكى بود يكى نبود غير از خدا هيرج كس نبود و اما قصه آدم ................ 


\section{الاغتراب فى قصة "آدم" لزهر ا خوش نظر دراسة تحليلية}

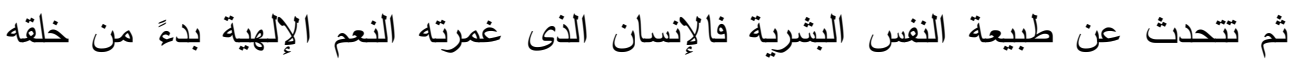

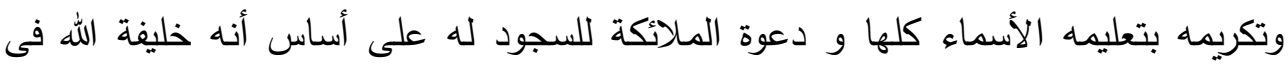
أرضه ، قد دفعته نفسه الضعيفة إلى معصية الله عز و جل مما أدى إلى هبوطه إلى

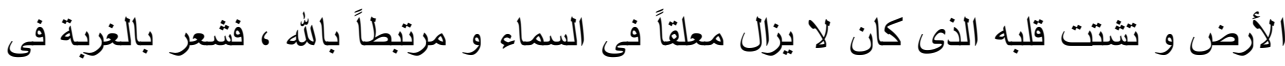
موطنه الجديد ( الأرض ) ، فنصفه أرضى و نصفه سماوى ، تتصارع روحه مع جسده ، فروحه تتعلق بالسماء أما جسده فمن التراب ، و هذا الصراع مستمر إلى أن يسيطر أحدهما • على الآخر

فمكان الإنسان ليس الأرض ، فهى ليست موطنه الأصلى ، لذا فهو مغترب و أسير فيها مثله مثل يوسف عليه السلام الذى سقط أسيراً فى سجن الدنيا ، و عليه ( الإنسان )

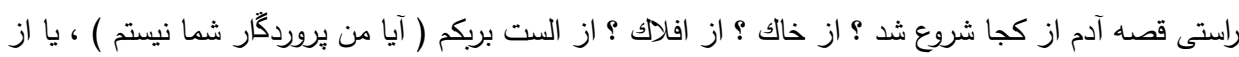

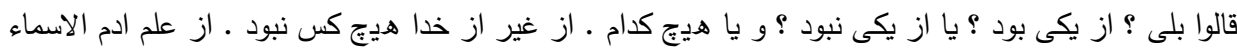

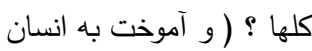

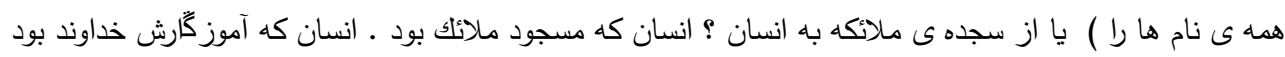

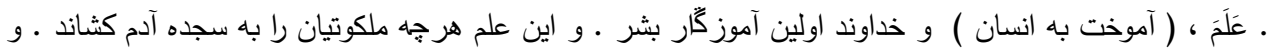

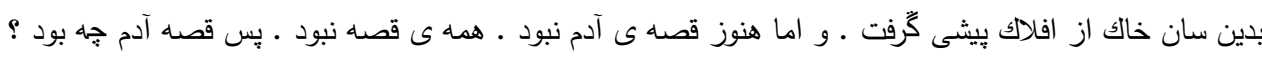

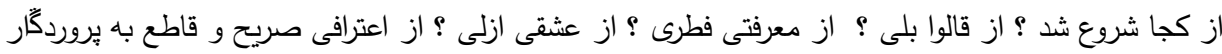

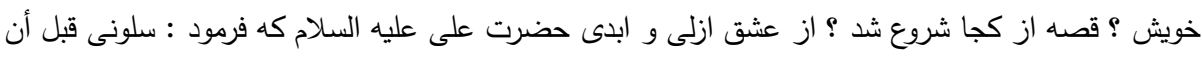

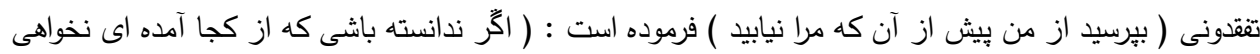

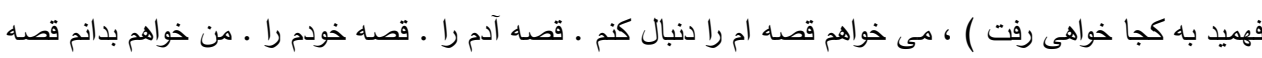

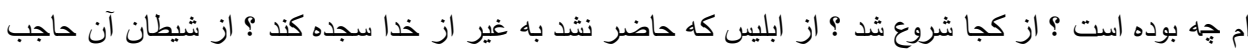

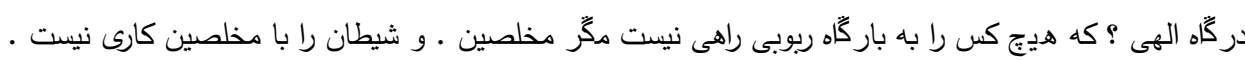

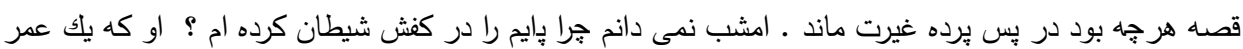

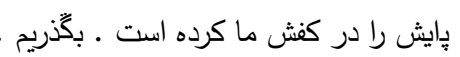

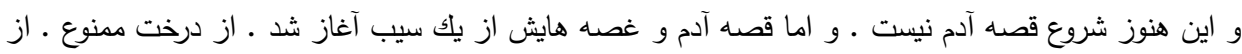

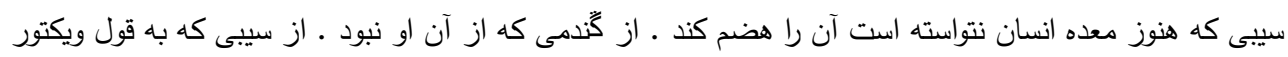

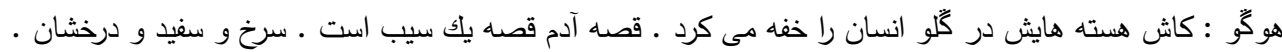

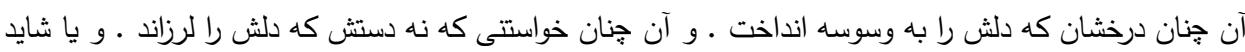

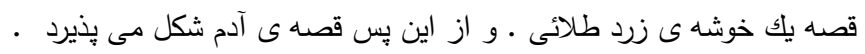


أن يتخلص من هذا السجن و من تلك الغربة لكى يعود مرة أخرى إلى موطنه و تهدأ

روحه المتألمة و يستريح و يشفى قلبه العليل ، فتقول الكاتبة :

و تبدأ انحداراتها و ارتفاعاتها بقطف تفاحة من الشجرة المنوعة .

كانت التفاحة تلمع أمام عينى و كانت شمس النفس تعكس أشعتها الذهبية على فروعها و أوراقها و صورة التفاحة المثيرة كانت تمنح الحياة فى صدرى الشجرة الممنوعة و شمس النفس الذهبية و ظهرت يداى بقدر الرغبة فى تفاحة على غصون وسوسة مخيفة و لكن أخرجت قلبى الموهوب من صدرى و فجأة استردت التفاحة الحياة فى يداى وني احتى كانت ساخنة و ممتلئة بالخفقان و جعلتىى ضرباتها أعانى من خوف مرعب و ضغط أصابعى داخل التفاحة و أصبحت التفاحة فى يدى رمانة ممتلئة بالشقوق و رأيت قلبى قد أصبح ألف قطعة و لا تزال التفاحة تلمع فوق الغصن ماذا كنت أفعل مع قلبى ؟ لا زال دافئاً و خافقاً بشدة ، و تنزف الدماء من أكفى و أغرقت قلبى الدافئ الممزق فوق غصن مزهر ذو أشواك . و تشبث صدرى المحترق و الخائف بروحى • و عقدت قلبى المجروح على أغصان التضرع و هربت منه و لو أن الإنسان يهرب فهو يهرب من ذاته

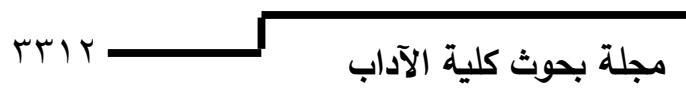


الاغتراب فى قصة "آدم" لزهرا خوش نظر دراسة تحليلية

$$
\text { لم يتبق لى مكان آخر فى الجنة }
$$

سقطت من السماوات إلى قلب الأرض مجروحاً ، ظمآناً ، عاجزاً ، مضطرباً و مشرداً فى

صحارى مرعبة و يائسة

على الرغم من أن قلبى المجروح و النازف قد تعرقل فى أغصان الحياة المزهرة فى الملكوت

و ظل فى نفس المكان ، أما أنا فقد أحضرت مع نفسى هدية قيمة و جوهرة فريدة ، ذات

$$
\text { ور نورٍٍ سماوي إلى الأرض من عالم الأمر الإلهىى فيه من روحى }
$$

من سوى الإنسان جدير بتملك هدية الله الملكوتية

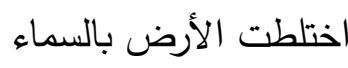

نصف أرضى و نصف سماوى

جذبنى نصفى الأرضى إلى التراب

فجاذبية التراب تستدعى التراب إليها ، و تتشأه فى نطاق طبيعتها فيظهر التراب لكن بمجرد أن يستيقظ من سباته الشتوى يأخذه هواء العشق

و يظهر نصفه الربانى و روحه السماوية و يفتح الأجنحة لتمر من السماء رويداً رويداً .

$$
\text { القدم فى التراب و الرأس فى الملكوت }
$$

عندما يكسر الإنسان سباته الشتوى يتعلق قلبه بالربيع و تثر بذرة المعرفة المختفية فى

$$
\text { طينته و تتمو و تصير يانعة . }
$$

و بذرة المعرفة التى تثر فى كل قلب تربط روحك بالعرش و تعزف دائماً داخل روحك لحناً حزيناً لكنه مثير و سماوى و يهمس نداء الملكوت الخالد دائماً بحب فى أذن روحك لقد أتيت من السماء و الأرض ليست مكانك على الرغم من أن قدرى المحتوم جذبنى إلى الأرض 
و على الرغم من أن هبوطى الحزين قد لوثنى بالتراب و على الرغم من أن قلبى قد أصابه الصدأ و على الرغم من أن طرف ثوبى قد تلوث بشدة ، على الرغم دن أن هذا الطين سئ الرائحة اللزج قد صنع لى قفصاً ضيقاً و على الرغم .

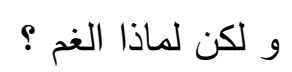
أنا الذى طبعى من التراب و ماذا أقول إن تلوث طرف ثثبى بشدة

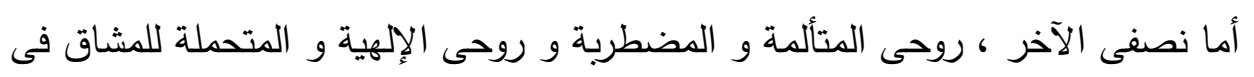

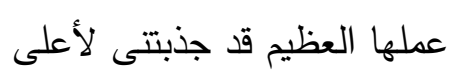
استدعانى صدى صوت سماء العشق إلى العالم الأعلى و قدمى ملتصقة بالأرض لـ لألى ذكرى الموطن الأصلى تجعل قلبى ممتلئًاً بالألم

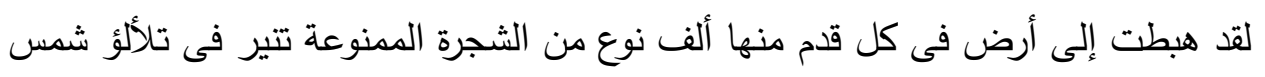
النفس و تستدعيك فاكهتها غير المقطوفة إليها كنت يوسف ربانياً سقطتُ أسيراً فى سجن الدنيا الضيق كنت أحيا فى السماء حيث كانت تتألق آلاف الثموس المضيئة على روحى ، و كنت ألمع كماسة فريدة فى تلألؤ النور ظل الملكوت متحيراً من خلق الإنسان لكننى الآن أسير عتمة الدنيا فى بئر مخاوفها متعدد الألوان و يدى و قدمى أسيرتان فى الإسى أغلال و قيود النفس العاصية القاسية و هناك ألف نوع من الحيوانات السامة و المفترسة فى وجودى أفر من أى منها ؟ و كيف أفر ؟ و قصة آدم الذى جُذب إلى الأرض لا توجد قصة حزينة أكثر منها 


\title{
الاغتراب فى قصة "آدم" لزهرا خوش نظر دراسة تحليلية
}

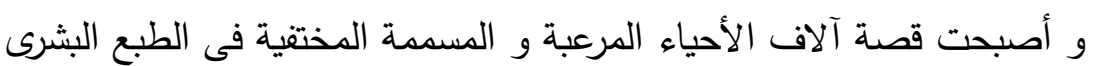

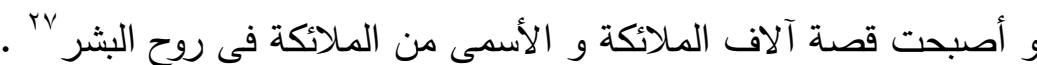

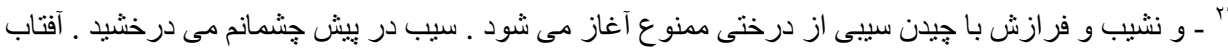

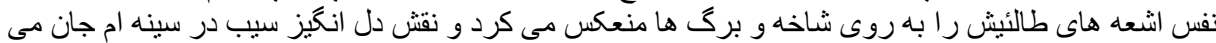

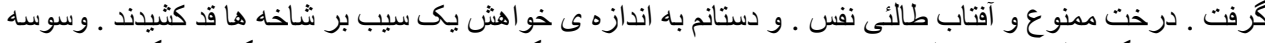

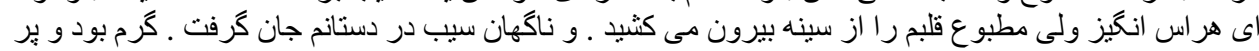

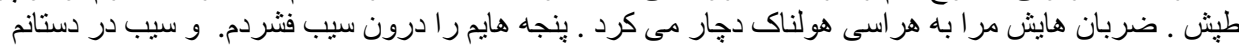

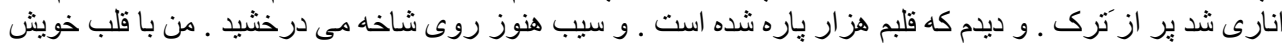

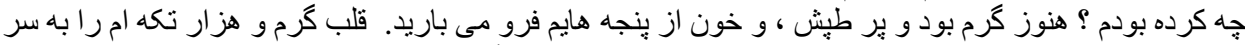

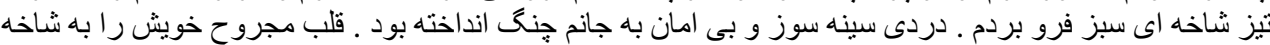

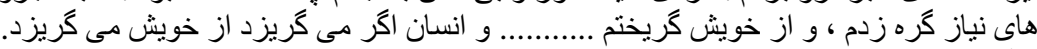

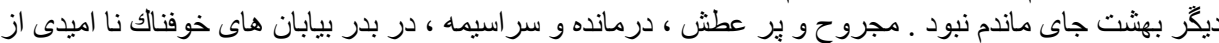

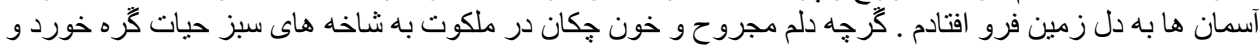

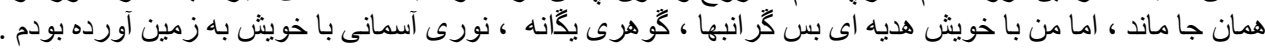

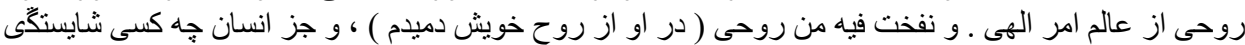

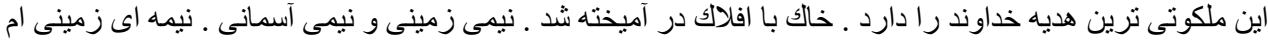

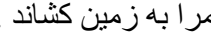

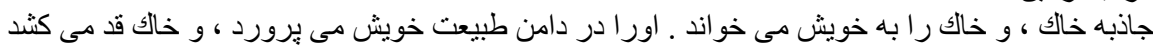

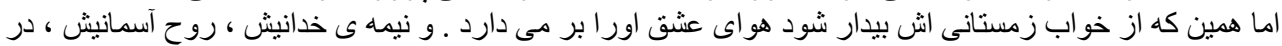

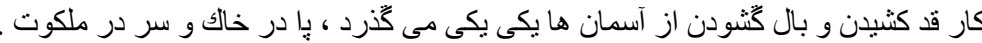

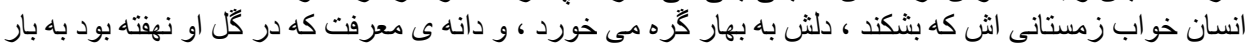

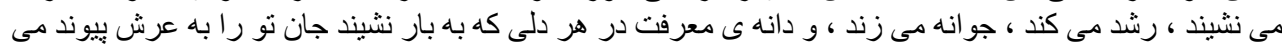

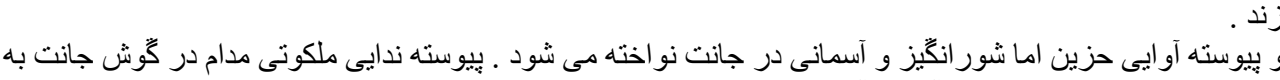

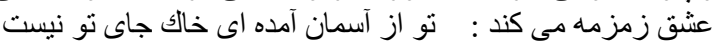

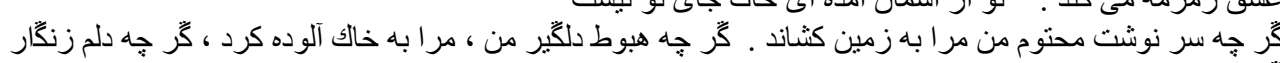
،

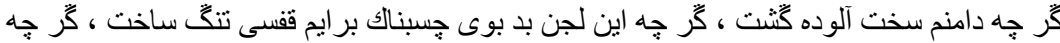

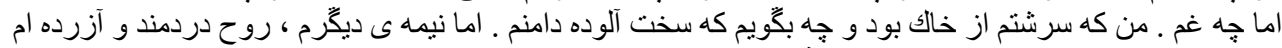

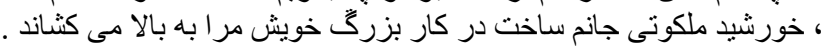

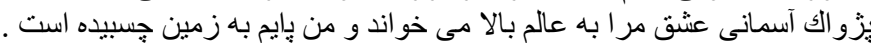

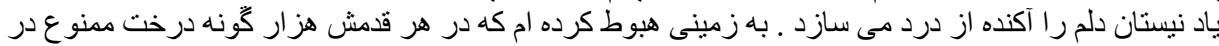

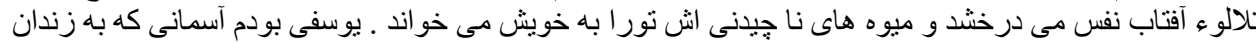

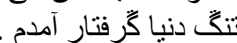

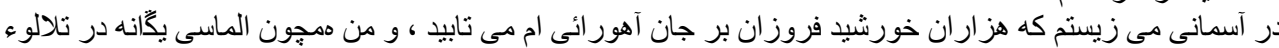

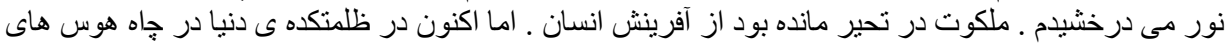

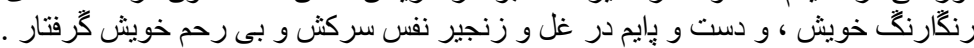

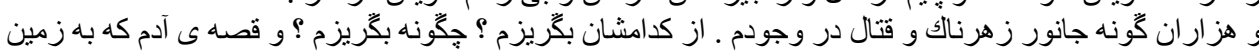
كثبده شند

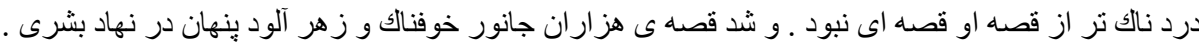

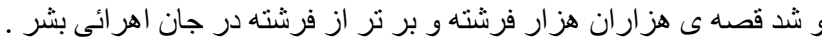


ثم تبدأ الكاتبة مرة أخرى فى تساؤلاتها التى تتم عن الحيرة و الإحساس بالاغتراب ، اغتراب

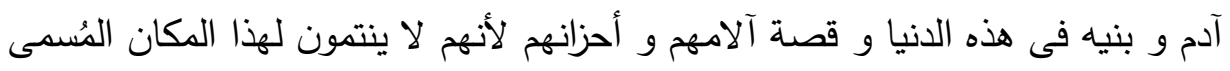

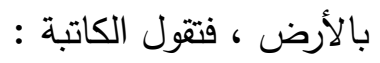
: إلهى من أنا ؟ أى شخص أنا ؟ كيف يخلق الألم النفس و كيف يبقيها على قيد الحياة ؟ كيف أستطيع أن أحمل على ظهرى

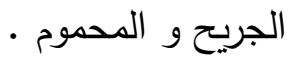
لم يتبق لاى ألم لأنه لم يتبق لاى رأس و لم يتعلق قلبى بأى مكان فى الأرض •

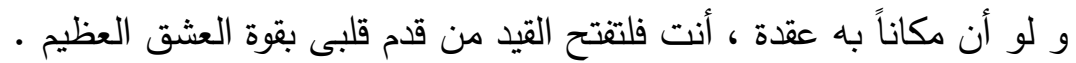
حقاً لو لم تكن السماء فكيف كان يستطيع الإنسان أن يظل فى الأرض و يعيش بها لتهات فالسماء نافذة مفتوحة تتجه إلى الخلود السماء هى حفرة سجن الدنيا الضيق قصة آدم هى قصة الاضطرابات ، قصة البكاء بلا سبب قصة جنون روح متألمة و حيرتها

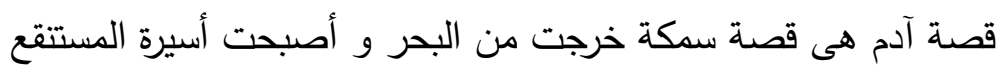

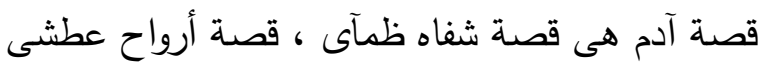
قصة طائر أسير و جريح و عاجز فى شبكة الصياد قصة الغربة ، قصة يوسف الذى سقط أسيراً فى مدينة العميان قصة آدم هى قصة عشق ، لكنه عشق حقيقى و ليس مجازاً

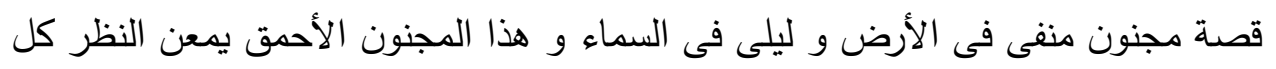
لحظة فى السماء لأن الأرض ليست مكانه قصة آدم قصة الترددات ، قصة غزليات العشق لاءق الاصن قصة كلمات لم تُقال ، قصة روايات لم تُكتب

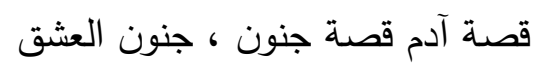




\section{الاغتراب فى قصة "آدم" لزهر ا خوش نظر دراسة تحليلية}

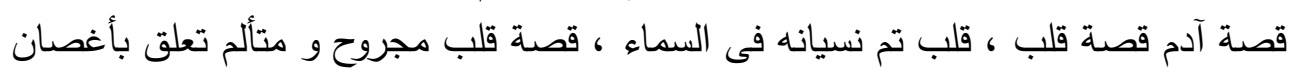
الحياة المزدهرة قصة آدم قصة الافتتان قصة آدم قصة صدر ممتلئ بالألم

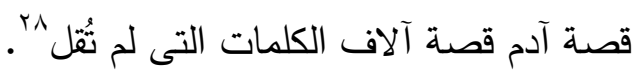
ثم تستطرد الكاتبة فى شرح رؤيتها عن قصة آدم موضحة أن الإنسان عندما يجد نفسه و يعلم أنه مخلوق إلهى و أن الله قد وهبه سر المعرفة و سر الإرادة المستقلة التى تختار

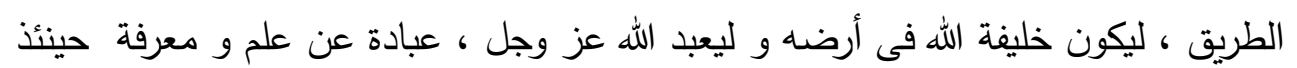

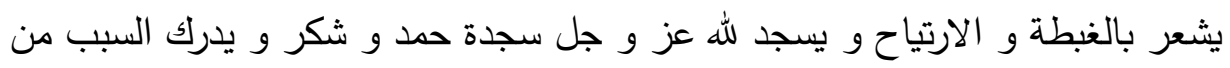

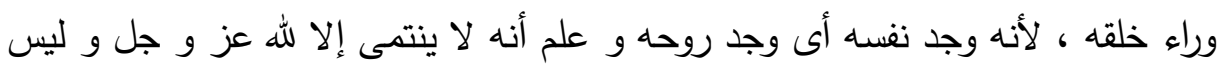

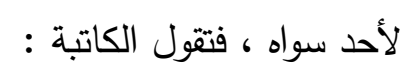

و أنا الذى كنت فى السماء فى ملكوت الله ( عز وجل) خُلقت من العدم بإرادة ( إله العشق)

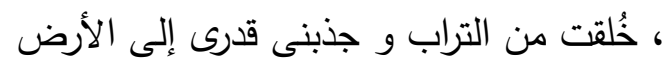
لكن عندما ظهرت فى الأرض ، عندما مر الشتاء و تعلق قلبى بالربيع وجدت بذرة سماوية

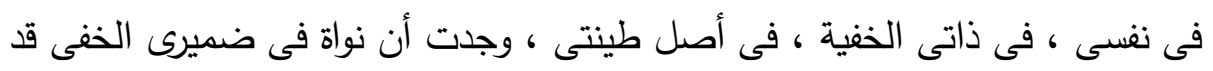

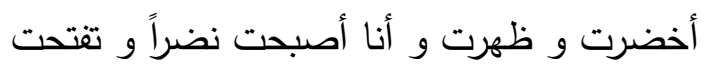

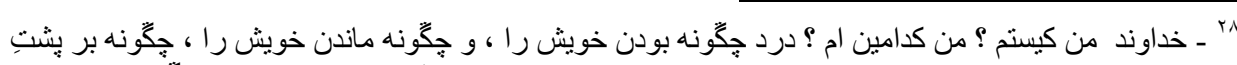

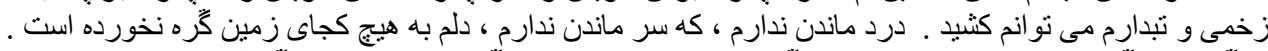

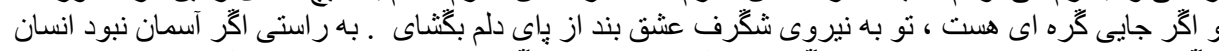

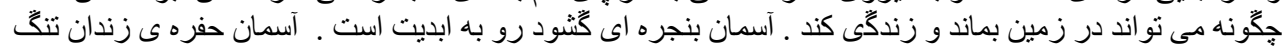

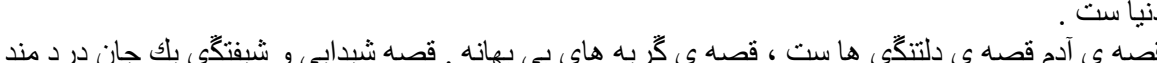

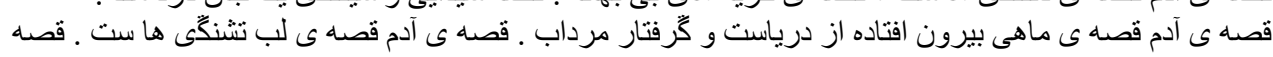

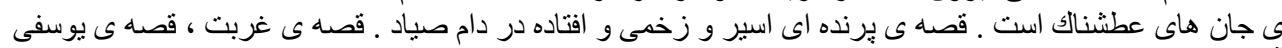

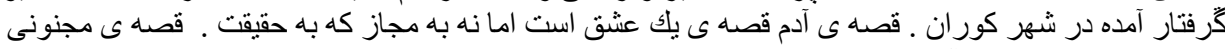

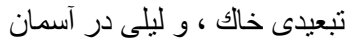

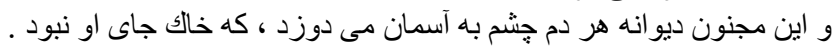

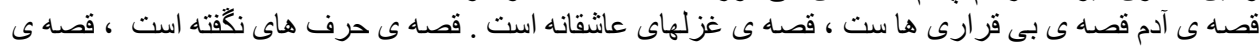

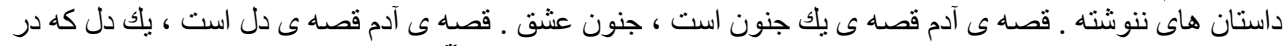

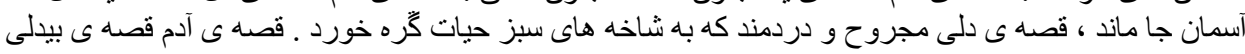

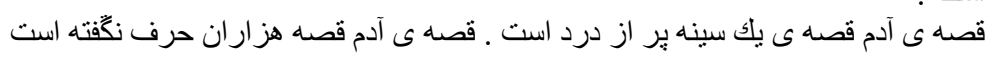


و رأيت أنه أثناء صنعى و أثناء خلقى و عندما كان يشكل طينتى ، عندما كان يجيب الملائكة قائلاً : " إنى أعلم ما لا تعلمون "، كان قد زرع بذرة عشق فى قلبى مختفية عن الملائكة المقربين و

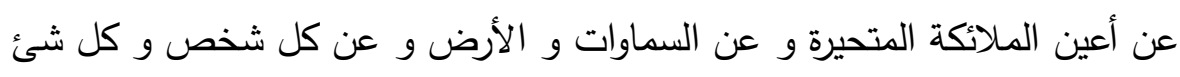

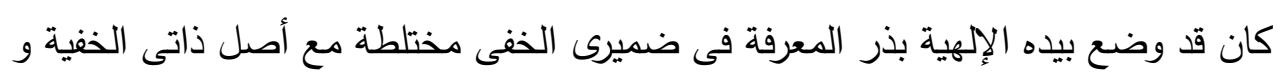

$$
\text { و قدرى و فطرتى • ثن كانت هذه قصة آدم . }
$$

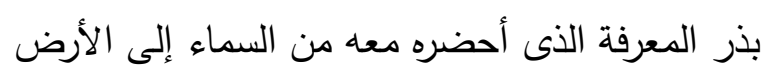

$$
\text { بذر العشق }
$$

و من جديد كان بستانيه الله نفسه

$$
\begin{aligned}
& \text { و رأيت أن قصة آدم هى قصة عشت بـانه } \\
& \text { وجدت بذرتها فى نفسى } \\
& \text { و أدركت أنه حينما قال : } \\
& \text { و" ما خلقت الجن و الإنس إلا ليعبدون " }
\end{aligned}
$$

أن الهدف من خلق البشر ، الهدف من خلق الجن و الإنس هو العبادة . لإنس

$$
\text { لكن العبادة غير مدكنة إلا بالمعرفة }
$$

لكن الشخص الذى أدركه و وصل إلى معرفته يسجد له دون اختيار و من منطلق الحاجة و التضرع و العشق فى سلطانه الإلهى و بقول " فيكتور هوجو" الكاتب الفرنسى : توجد لحظات فى الحياة تكون الروح فيها فى

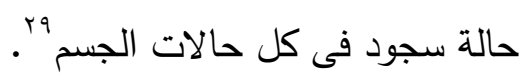

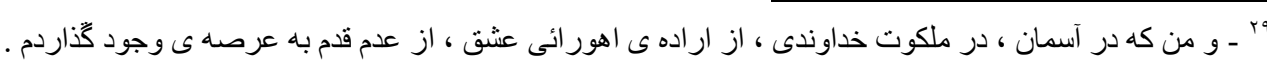

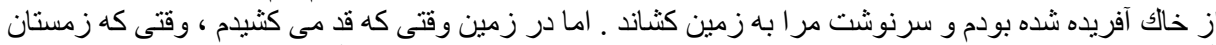

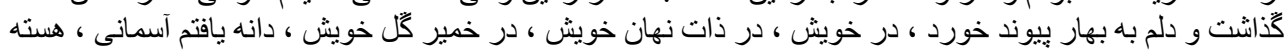

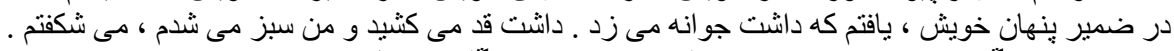

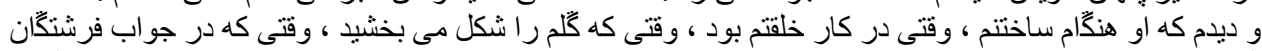

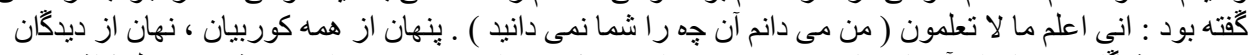

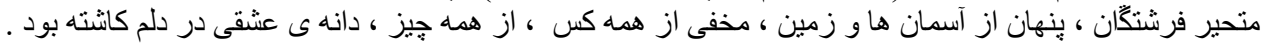

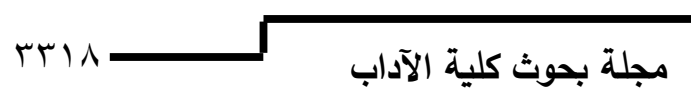




\section{الاغتراب فى قصة "آدم" لزهرا خوش نظر دراسة تحليلية}

ثم تعود الكاتبة إلى الأسئلة الوجودية المحيرة التى أصابت بنى آدم جميعهم بالحيرة مرة

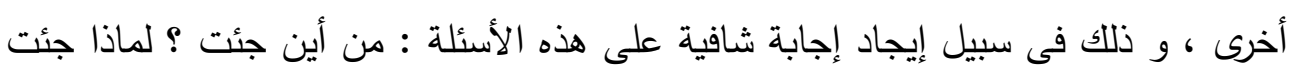

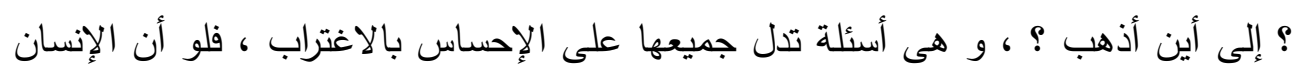

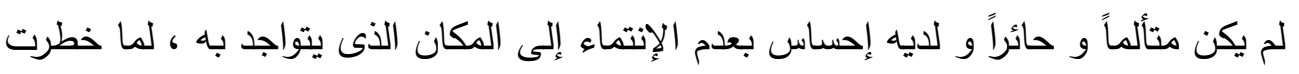

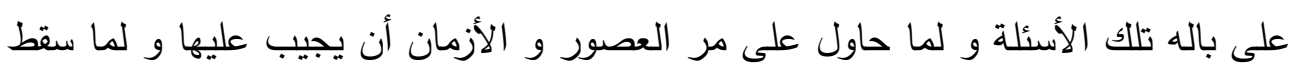

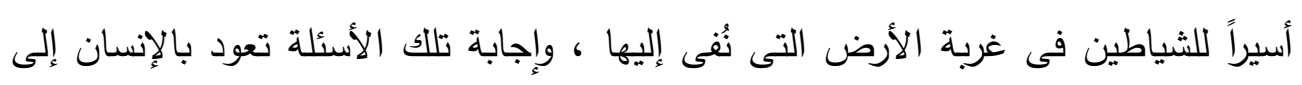

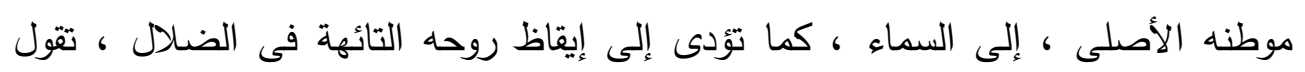

$$
\text { و لا تزال قصة آدم مستمرة إلى الآن • }
$$

و آدم فى ذهنه الباحث يطوى عالمه الخارجى و الداخلى خطوة خطوة فى إثر الإجابة على الثى

ثلاثة أسئلة مهمة لحياته :

$$
\text { من أين جئت }
$$$$
\text { لماذا جئت ؟ من جن }
$$

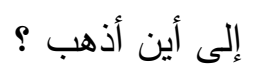

و أنا دائماً أسافر من نفسى و لسنوات داخل ذهنى ، داخل روحى المتألمة و المضطربة

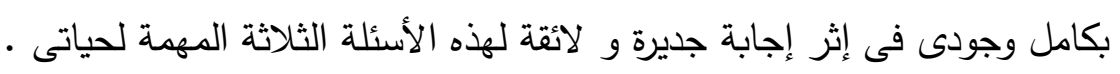
سافرت داخل نفسى إلى أن رأيت ذلك المكان الذى أسمع فيه إجابة أسئلتى

$$
\begin{aligned}
& \text { وجدت نفسى فى السماء فى جواب " ألست بربكم " ؟ }
\end{aligned}
$$

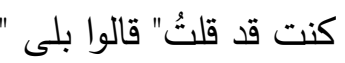

$$
\begin{aligned}
& \text { وجدت نفسى مسجود الملائكة }
\end{aligned}
$$

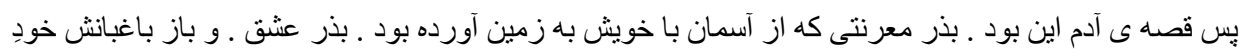

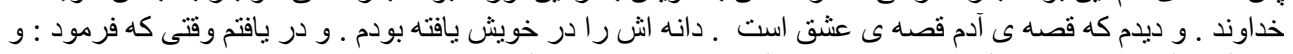

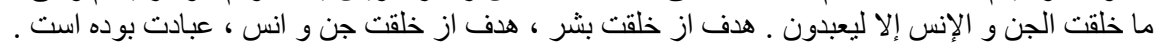

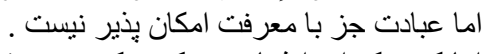

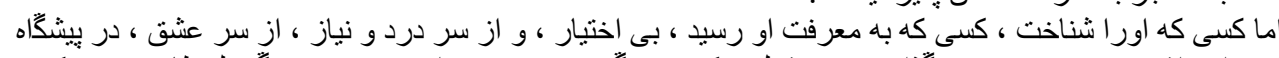

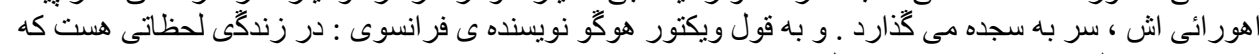

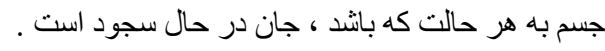




$$
\begin{aligned}
& \text { وجدت روح الله نابتة داخل نفسى } \\
& \text { و كنت قد أصبت الملائكة و العالم القدسى بالحيرة } \\
& \text { كان كل شئ سماوى }
\end{aligned}
$$

و كنت قد رأيته جمالاً أبدياً و كمالاً لا متتاهى و نوراً مطلقاً ، كماء

$$
\text { و كنت قد وجدت عشقه فى السماء • }
$$

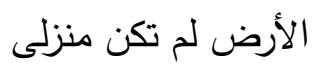

كنت قد رأيت من قريب راحة قلبى و معشوقى السماوى و اله عشقى و الخير المطلق و مارول

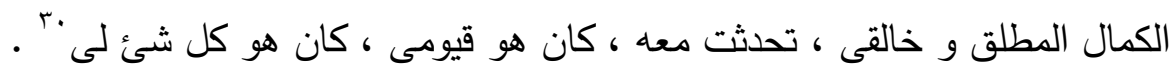
ثم تستعرض الكاتبة بعد ذللك حياة البشر على الأرض و الآلام التى كابدوها بعد أن تركوا

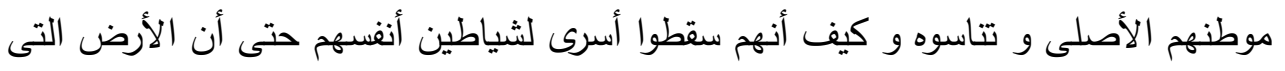
جعلهم الله خلفاء له فيها أصبحت تخجل من أفعالهم و عاد الإنسان مرة أخرى للأسئلة التى التى

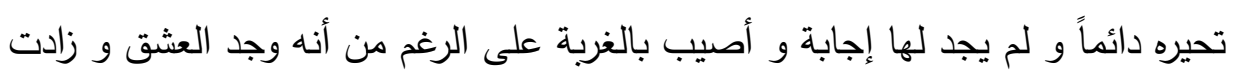

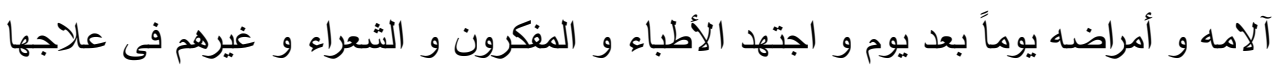

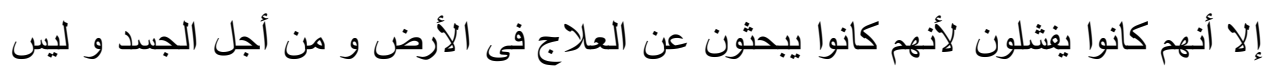
من أجل الروح ، تقول الكاتبة :

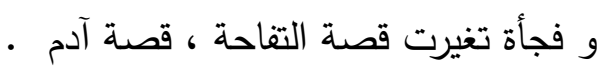

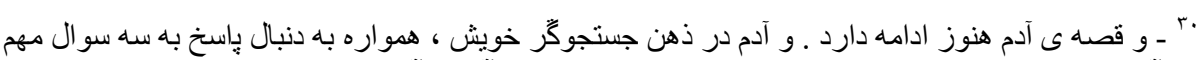

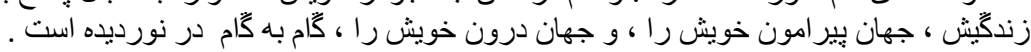

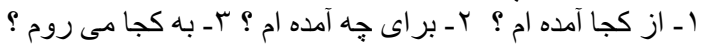

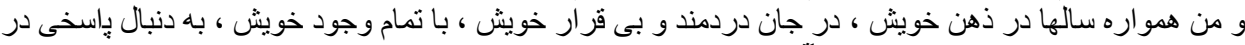

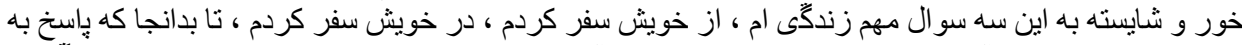

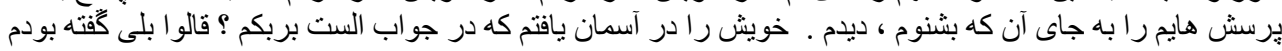

خويش را مسجود ملائك يافتم . روح خداوندى را در جان خويش دميده يافتم ـ فرشتخان و عالم قدس را به تحير كثانده بودم .

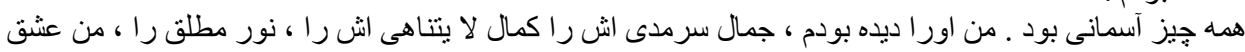

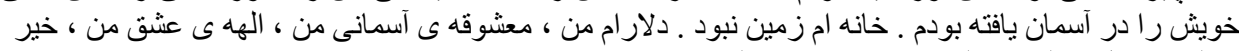

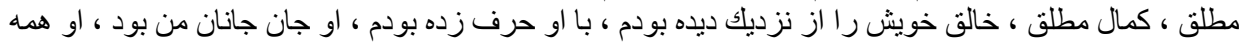
هيز من بود

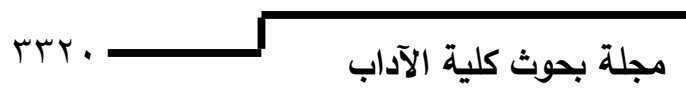


الاغتراب فى قصة "آدم" لزهرا خوش نظر دراسة تحليلية

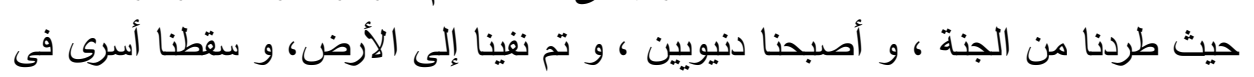
سجن الدنيا الضيق .

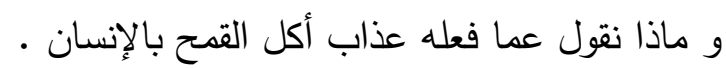

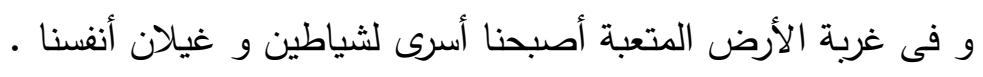

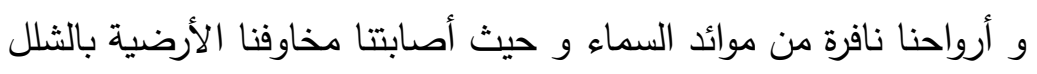

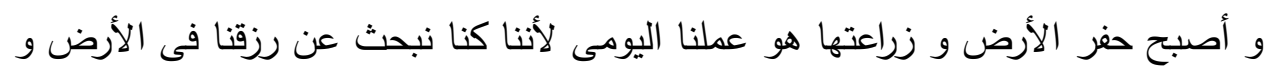

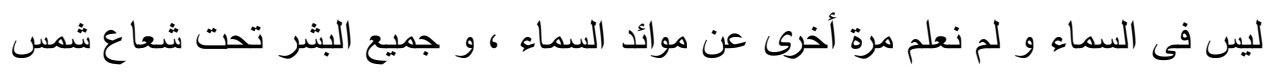

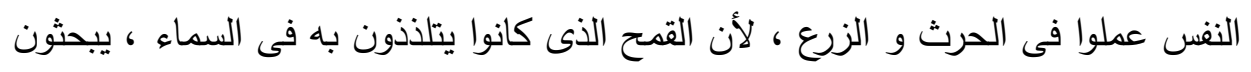
عنه فى الأرض .

و أيدينا مليئة ببثور الانتظار لأن الفأس و المنجل هما ما يمنحا قلبنا الأرض المحروثة و

$$
\begin{aligned}
& \text { ليس الأرض إينا ملينة بل } \\
& \text { و رزقنا جميعاً دم القلب الارضي }
\end{aligned}
$$

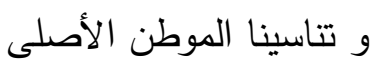

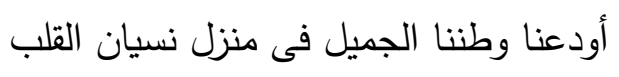

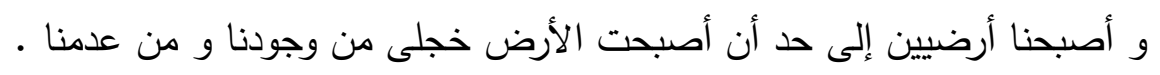

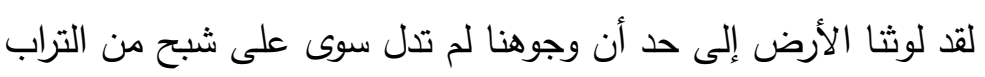

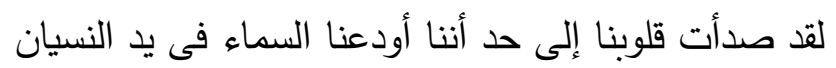
و فى ذلك المنفى عانينا و أكلنا خبزاً ملوثاً بدم القلب إلى حد الثى أننا اعتقدنا أن موائد السماء

$$
\text { هى أسطورة }
$$

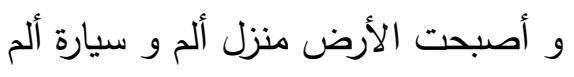

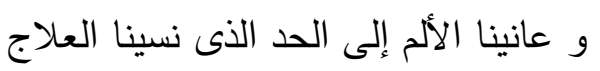
قلنا ليس لدائنا دواء الاء العائ

و أصبح الألم و المعاناة و ألم القلب هو رزق كل يوم لناء

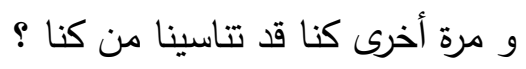
أين كنا ؟ 


$$
\begin{aligned}
& \text { د / هاله حسن كحمل } \\
& \text { كيف أتينا ؟ هاله } \\
& \text { ماذا حدث حتى جئنا ؟ } \\
& \text { ماذا يجب أن نفعل ؟ } \\
& \text { أين سماؤنا ؟ }
\end{aligned}
$$

وجدنا العشق فى أنفسنا لكننا كنا قد فقدنا معشوقنا ، علقنا القلب بالمئات من الأسى و

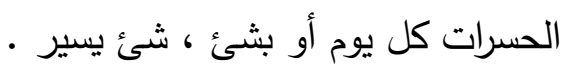

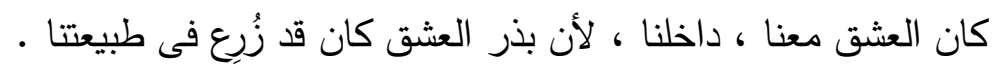

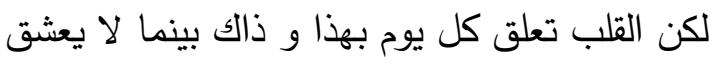

لأنه لو كان هذا هو العشق إذن لماذا تهيأت الراحة و الاستقرار للرحيل عن قلوبنا

$$
\text { و أصبحنا غرباء مع أنفسنا }
$$

و كل يوم أصبحت الأحزان ، الغفلات ، عدم وجود تجاوب فى الكلام و الوحدة هى آلام لا

$$
\text { علاج لها }
$$

كل يوم ألم جديد ، كل يوم معاناة زائدة

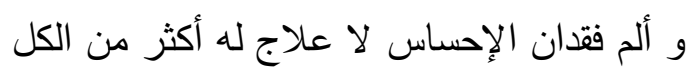

نأكل كل يوم خبز القهح ، و مرة ثانية الأحزان فى إثر الأخرى ، وكل امرئ بأسلوب

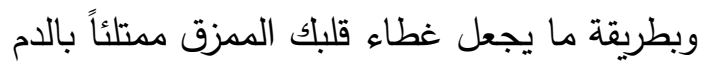

و كلما كان البشر مختلفين بآلاف الأفكار و الأذكار أصبح الجميع أطباء لنا

$$
\text { و ظهرت الأسماء واحداً تلو الآخر }
$$

و كل واحد نظرية و مناظرة و اسم جديد و مدرسة جديدة أى أن هذه هى الحقيقة .

$$
\text { أى أن هذا هو الإنسان هذه هي الحياة }
$$

و انشغل الكُتاب بالكتابة حتى يمنحوا البشرية النجاة .

من ماذا ؟

من ذلك المستتع الذى سعت إليه

و الشعراء كل منهم بقدر إدراكهم و شعورهم نظموا و دونوا

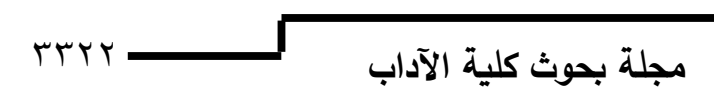


لكن ماذا نقول إن الإنسان عجز و اختار الألم

و إدراك الحقيقة ليس سهلاً دائماً

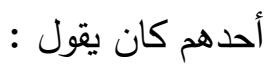

أولئك الذين أصبحوا وسطاً للفضل و الآداب

أصبحوا أصحاب الثمع في جمع الكمال لم يخرجوا من هذه الليلة الظلماء

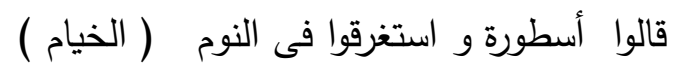

و أشعار من هذا القبيل

و لا أعلم لماذا لا يصدق أى شخص أن أن مثل هذه الأشعار هى للخيام .

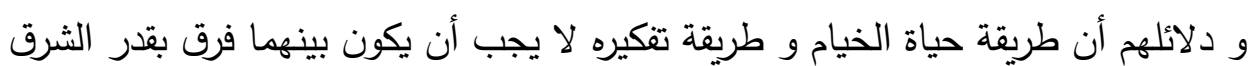
عن الغرب و ريما يقولون صدقاً و على أية حال هذا النوع من الأشعار منسوب إليه

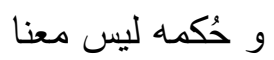

و ظهر آخرون و قالوا و كتبوا كلمات و ربما كانت أفكارهم نتيجة تجارب ناقصة لحياتهم

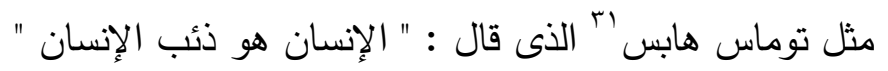

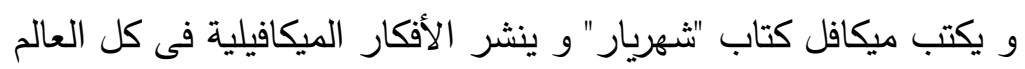
أو سارتر الذى قال :

يجب الحياة و لكن ليس للحياة هدف و فلسفة

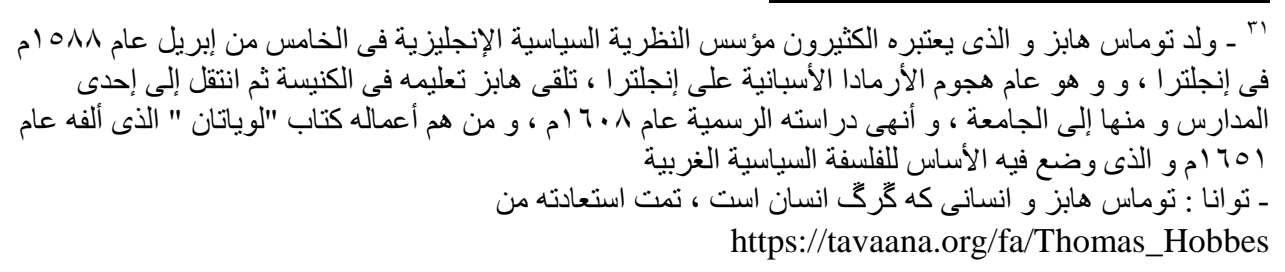

مجلة بحوث كلية الآداب

tht 
د / هاله حسن محمد

وجمل كثيرة من هذا القبيل

و البشر من هذا النوع و بمثل هذه الأفكار ليسوا قليلين

فلنمضى

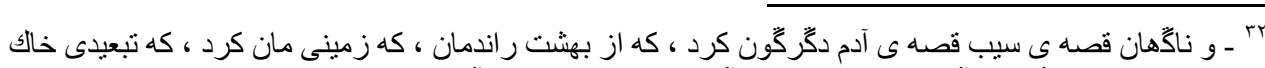

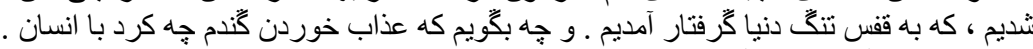

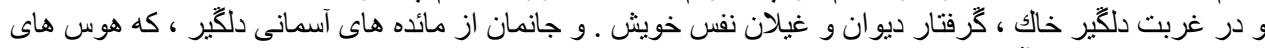

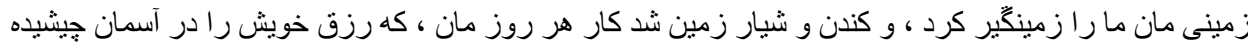

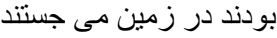

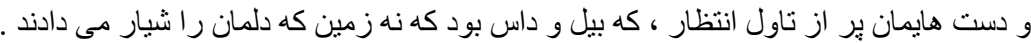

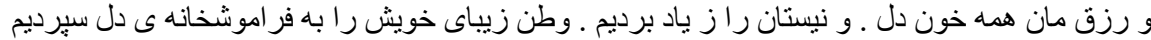

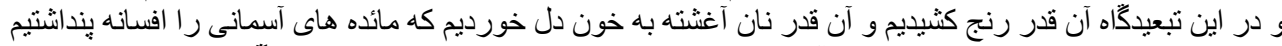

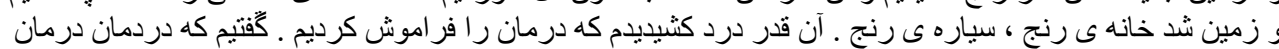
ندارد .

و درد و رنج ، وخون دل ، شد رزق هر روزمان ـ ديخّر از ياد برده بوديم كه بوديم ؟ كجا بوديم ؟ جِّونه آدديم ؟ جه. شه كه آمديم

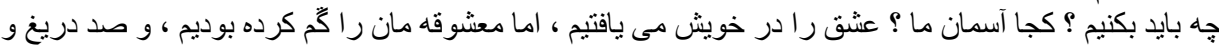

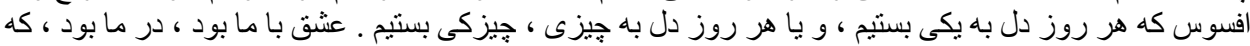

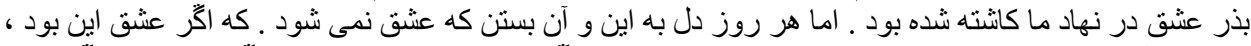

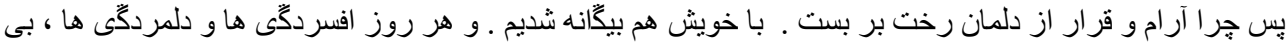

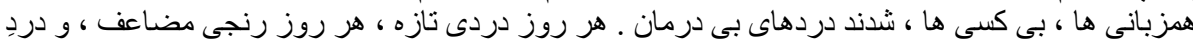

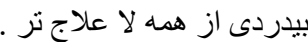

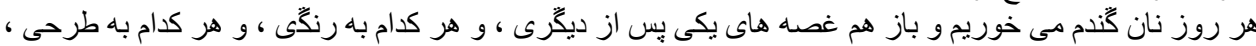

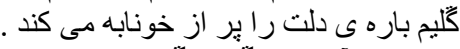

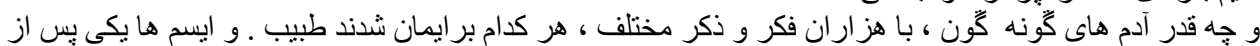

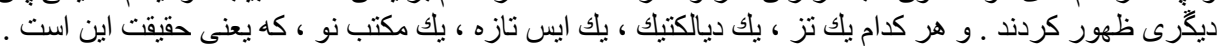

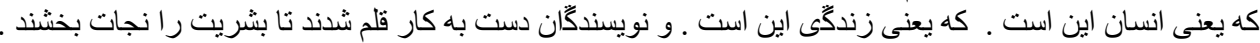

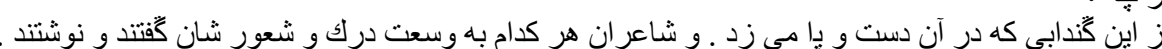

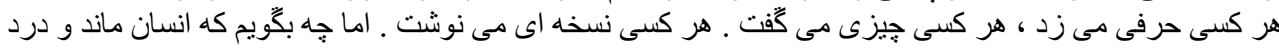
انتخاب . ركئ.

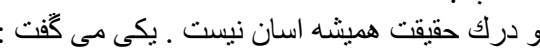

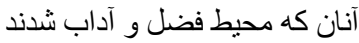

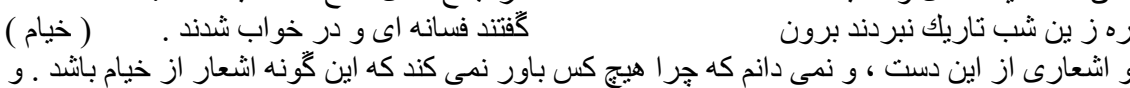

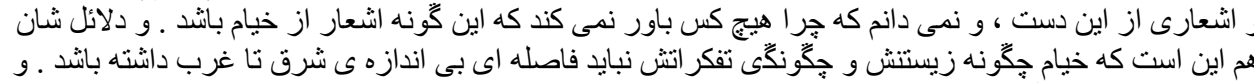

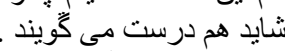

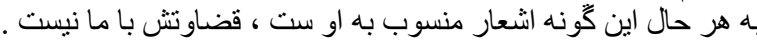

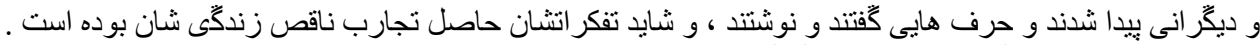

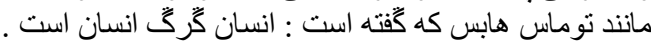

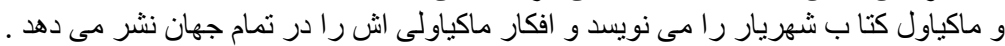

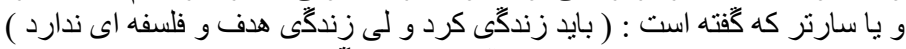

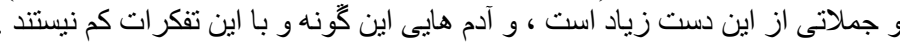
بقغّريم

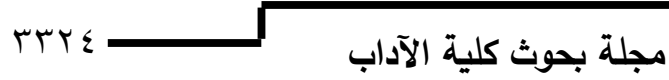




\section{الاغتراب فى قصة "آدم" لزهرا خوش نظر دراسة تحليلية}

و تستمر الكاتبة فى الحديث عن آلام البشر التى فثلوا في إيجاد علاج لها ، و تذكرنا أن

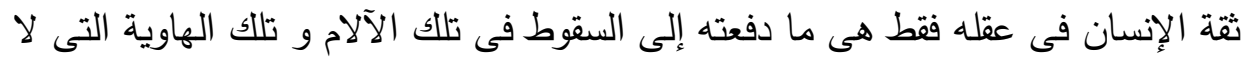

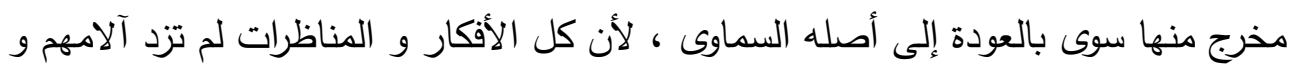
أحزانهم إلا حدة لأنهم ابتعدوا عن طريق الحق و نسوا خالقهم ، فألم الإنسان هو ألم الإلحاد الاد الإن

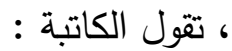

و فى هذه الدنيا و هؤلاء البشر ظهرت آلاف المدارس المادية و غير المادية و نُسيت بعد آلادي

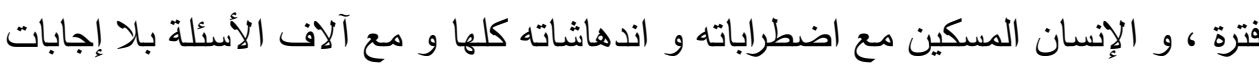
التى تستطيع أن تأخذك فقط إلى عيادة الطبيب على الرغم من أنها مصباح طريق العقل العاله

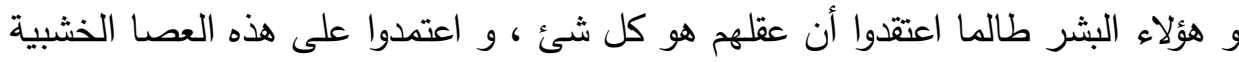

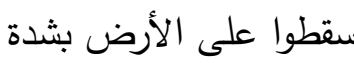

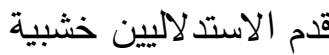
و القدم الخشبية شديدة الاهتزاز ( مولانا) و طالما اعتقد الإنسان أن عقله هو طريق الدصباح الوحيد بقى متحيراً فى ظلمة الظنون و

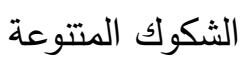
و قد قال شمسنا المضيئة والإلهية على عليه السلام : إننى التجأ إلى الله من البشر الذين يعيشون فى الجهل و يموتون فى الضيلال و البشر يتشبسون بكل ما يعلق بأيديهم من أجل علاج آلامهم غير القابلة للعلاج و الالآم

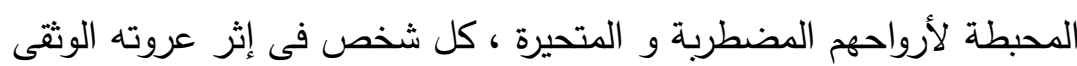

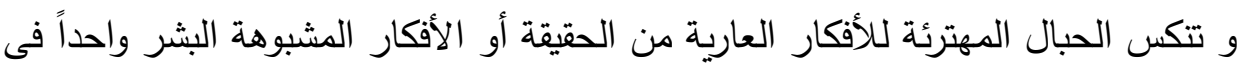
إثر الآخر فى بئز الضلال الفيال و لم يكن أى شخص يعرف أن ألم الإنسان ليس ألماً أرضياً ليقبل العلاج فى الأرض و من الأن

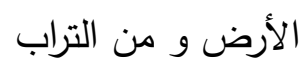

و لا تفيد الأسماء و تتبدد المناظرات المتتوعة جميعها و الإنسان يعانى الألم كالمعتاد

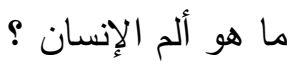

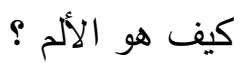


ألم الإنسان هو ألم الإلحاد بَ .

ثم تُسهب الكاتبة فى الحديث عن الحياة الحيوانية التى يعيشها الإنسان و التى أصبحت كل الإنى احتياجاته فيها هى احتياجات جسدية من مأكل و مشرب و مسكن و غيرها من الرغبات

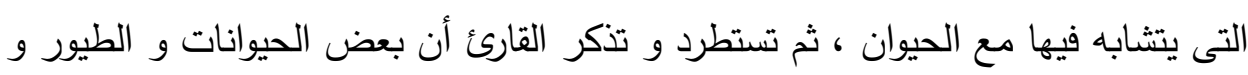

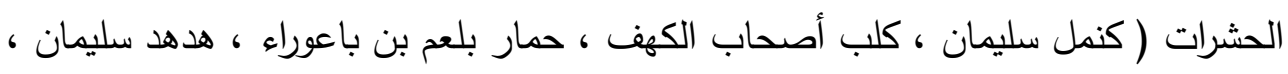

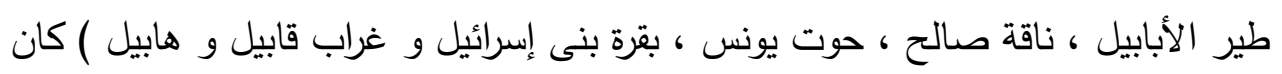

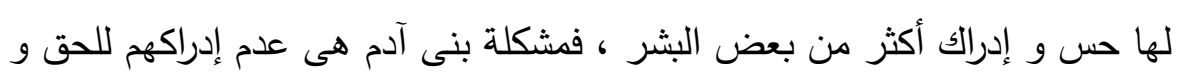

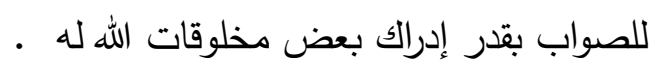

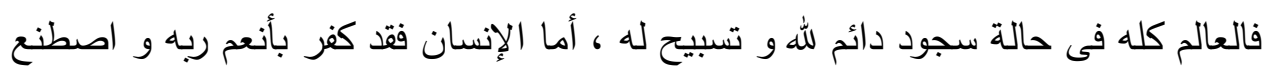

لنفسه آلهة من دون الله كبنى إسرائيل الذين اتخذوا العجل ، حينئذ أصبح الإنسان غريباً

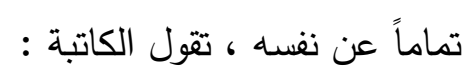
كان الإنسان يطوى شرق العالم و غربه فى إثر روحه الضائعة ، بعون

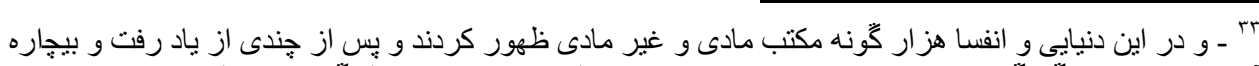

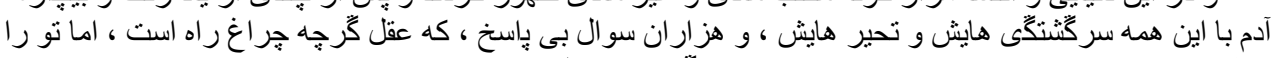

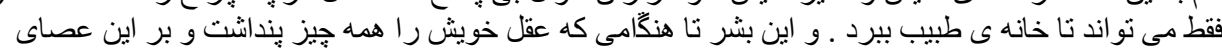

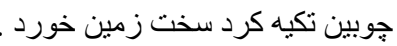

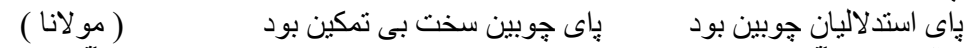

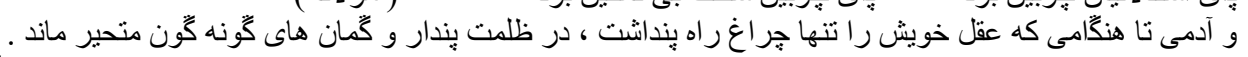

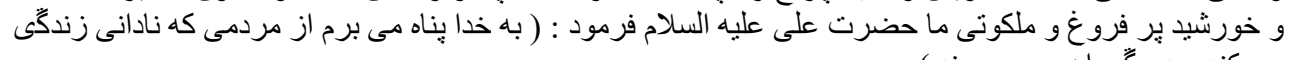

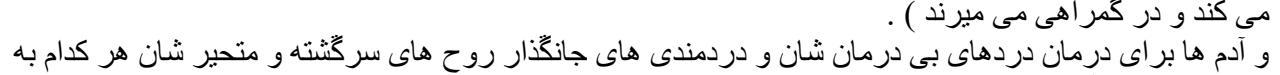

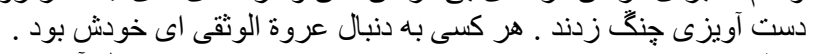

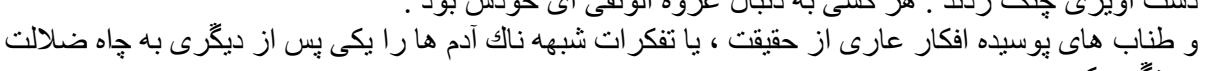

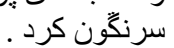

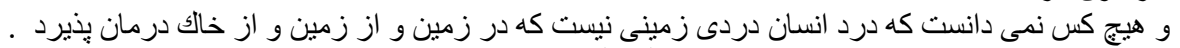

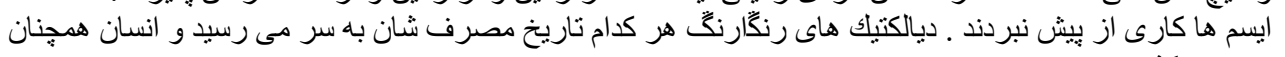
درد مى كثيد

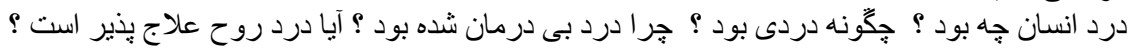

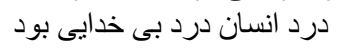

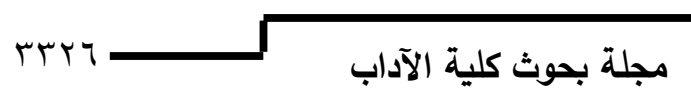


الاغتراب فى قصة "آدم" لزهرا خوش نظر دراسة تحليلية

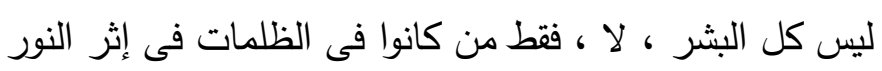

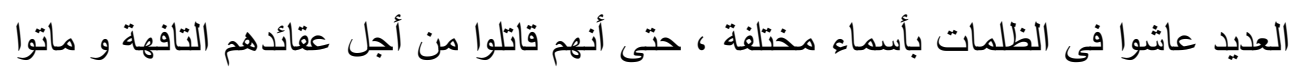

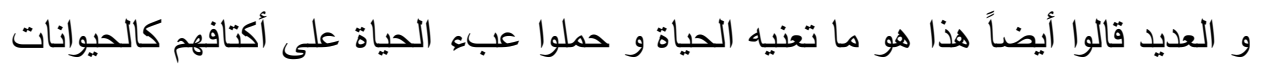

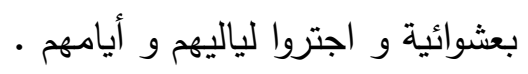
أصبحت الدنيا ككرنفال به جميع أثنكال الأحياء و قد تغير معنى الحياة ، الحياة تعنى الماء و العلف و الجميع منشغل بمعدته و عورته ، و و الأياء

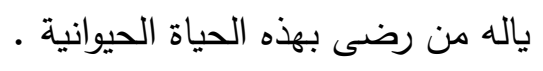
فيا مائة حسرة أن الحيوان يعيش إحساس الحياة الحياة بقدر إدراكه أليس كذلك أن كلب أصحاب الكهف قد حرس بعيون مفتوحة فى كهف الإيمان لثنلاث مائة عام

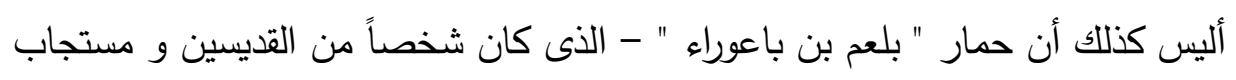

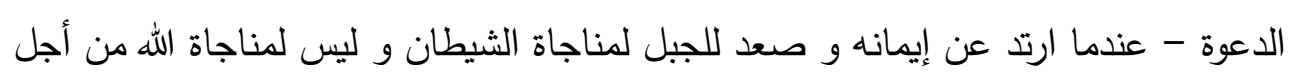

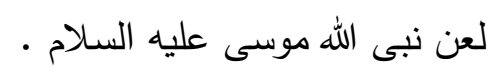

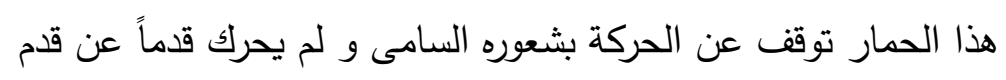

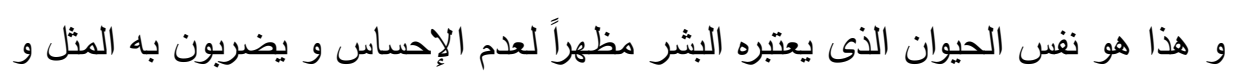

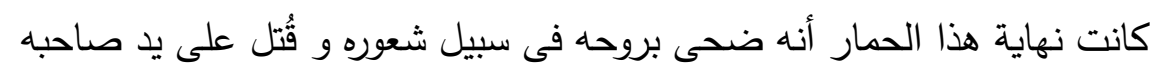

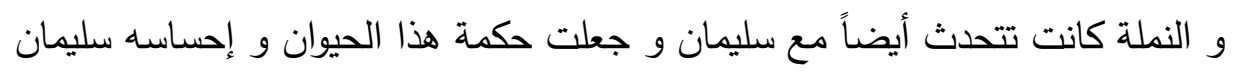
العظيم يشعر بالحيرة

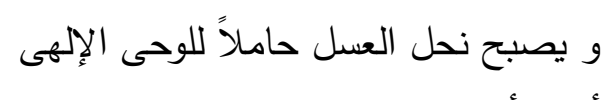

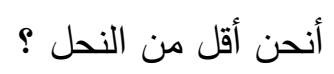

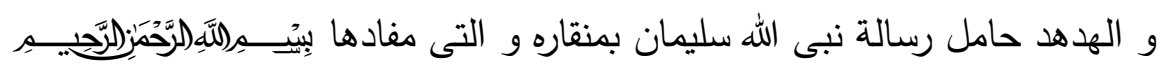
فأين هو عملنا ؟ لهد جأ ذللك الذى وجد بسم الله فى المنقار ليس بعيدأ إن وجد الكثير من الأسرار 
و الأبابيل ، تلك الطيور الإلهية التى تصبح جنداً للهو يصبح أصحاب الفيل كعصف مأكول . ، و ناقة صالح وُلدت من الجبل و أصبحت حجة إلهية على العباد . بينة من ربى و بطن الحوت محراب يونس ، الذى كان هذا الذكر على شفتيه: "لا إله إلا أنت سبحانك إنى كنت من الظالمين " حتى يتحرر من محبسه و ألم يكن قوم بنى إسرائيل وراء إيجاد بقرة داراً بدار و مدينة بمدينة ليذبحونها و تُحيي عظامها القتيل و الغراب معلم قابيل الذى كان يضرب بمنقاره دائماً فى الأرض و صنع من التراب حفرة

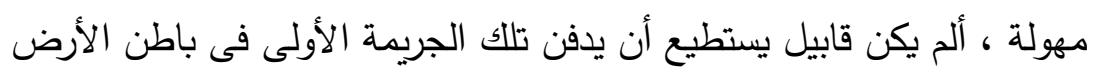

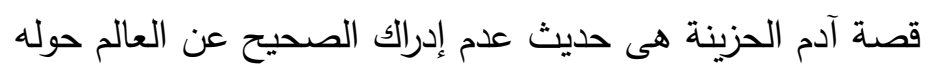
ألم الإنسان هو ألم الكفر العالم حولنا دائماً حى و مسبح و نحن صامتون و إدراك تسبيحهم يبقى خارج عن إدراكنا و عندما يسجد النجم و الشجر " و النجم و الشجر يسجدان "

و عندما يسلم الجماد و النبات و الحيوان ، بالمعنى الحقيقى للكلمة ، أى التسليم للأمر الإلههى و الإيمان بخالقهم

نفسنا الكافرة أحياناً تصنع من عجل السامرى تمثالاً ذهباً و تسجد أمام قدمه و أحياناً مثل هذا الميل إلى المادية و المادة و الطينية لا نعرف أنغسنا فى أية مرآة . و نصبح غرباء تماماً عن أنفسنا

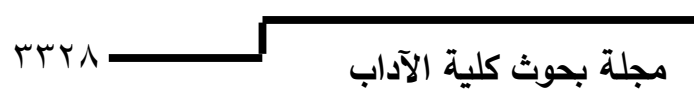




\section{الاغتراب فى قصة "آدم" لزهرا خوش نظر دراسة تحليلية}

فماذا حدث بمرآة القلوب الصدأة الملوثة فلم تأخذ طينتاءَ • ثم توضح لنا الكاتبة بعد ذللك رؤيتها لقصة آدم و هى أنها قصة انعدام الهوية ، فقد نسى الإنسان نفسه و الهدف من هبوطه إلى الأرض فشعر بالاغتراب و الانتماء إلى اللامكان و

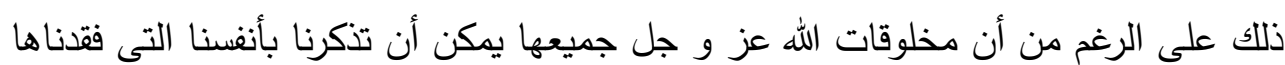

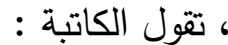
و أصبحت قصة آدم قصة انعدام الهوية

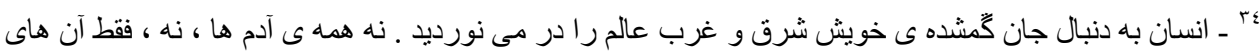

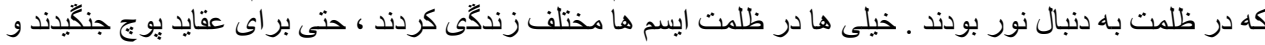

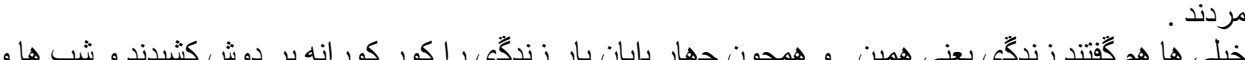

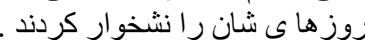

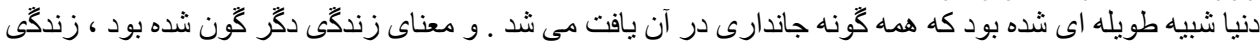

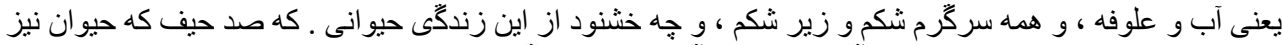

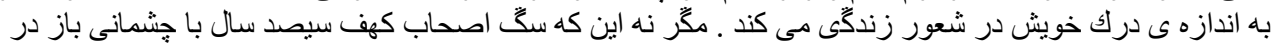

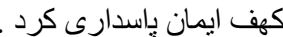

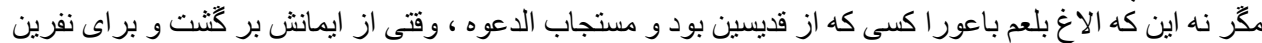

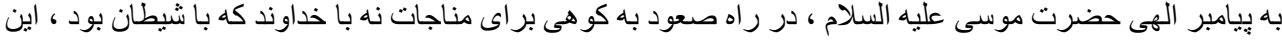

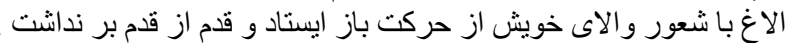

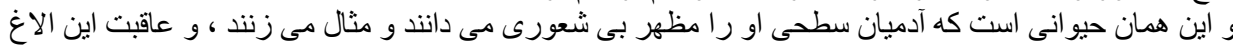

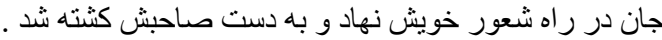

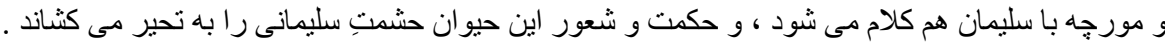

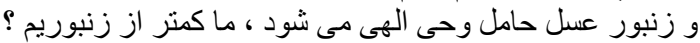

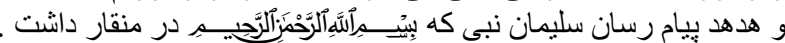

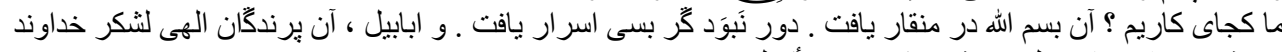

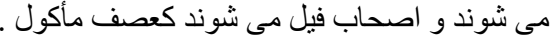

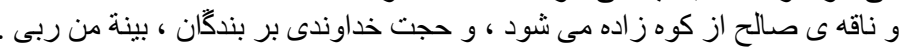

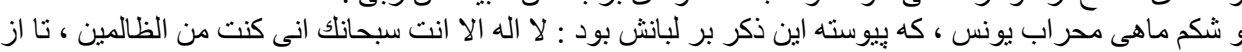

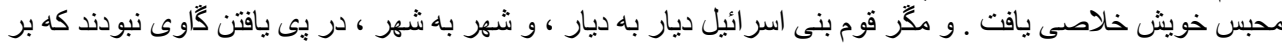

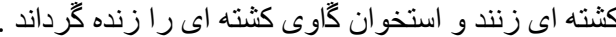

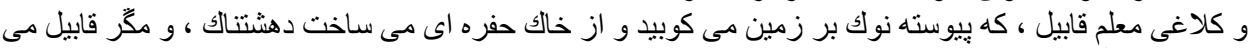

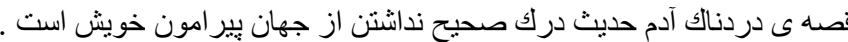

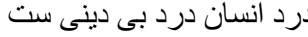

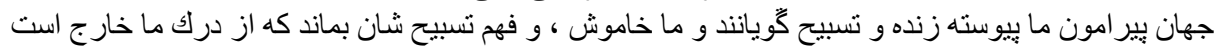

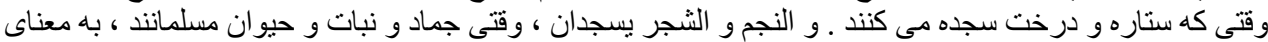

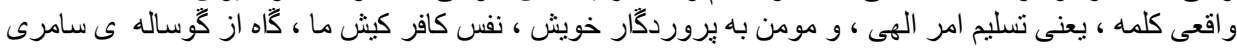

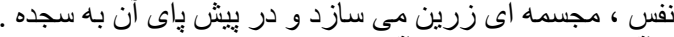

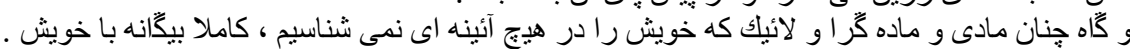

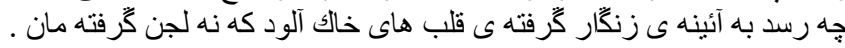


أحياناً عندما أنظر إلى العالم من حولى خاصة إلى الآلاف من أنواع الحيوانات المختلفة

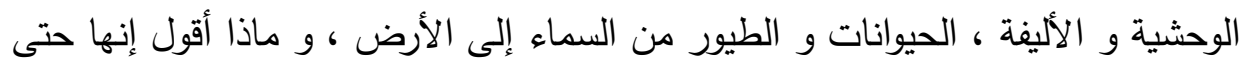

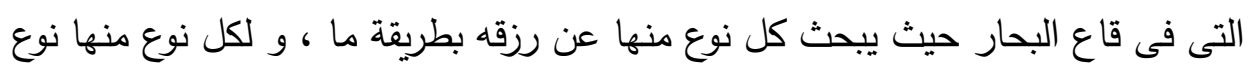

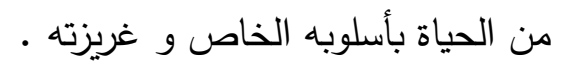
و كأننى أرى الجميع أشباحاً كل منهم جدير بالعيش داخل روح الإنسان .

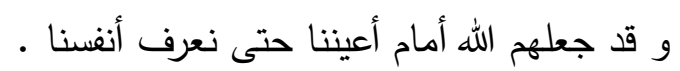
أو نعرف أفضل أن صفة كل حيوان فى وجودنا و كأنه يعيش فى أنفسنا وأ رواحنا و نحن فقط نرتدى جلد ابن آدم على أنفسنا

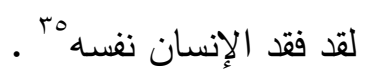
ثم تقول الكاتبة أن قصة آدم هى قصة القلب ، لكن القلب الحى و لأن هناك الكثير من موتى القلوب الذين يعيشون على وجه الأرض ، فقد أرسل الله عز و جل الأنبياء ليكونوا

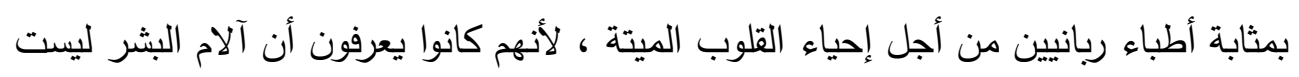

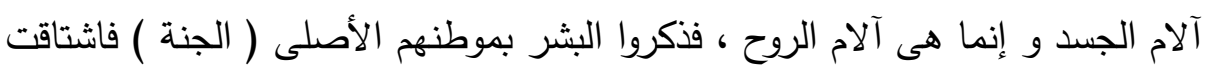
قلوبهم و أرواحهم إليها و إلى رؤية وجه الله عز و جل و زال صدأ قلوبهم و أينعت بحب الله الله

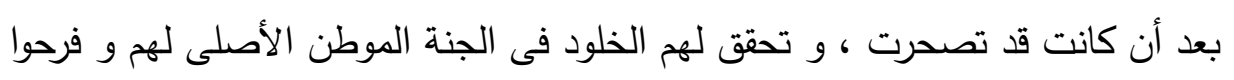

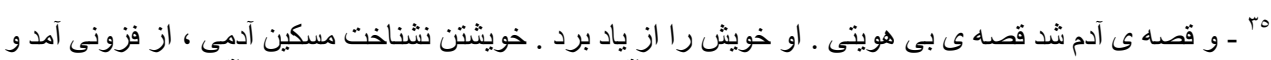

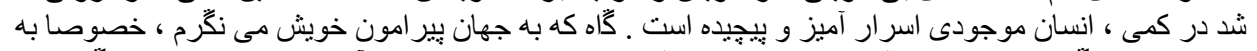

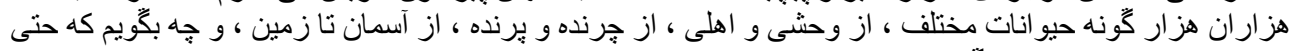

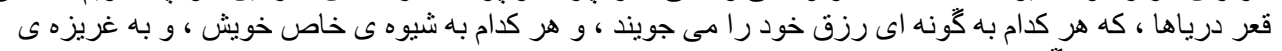

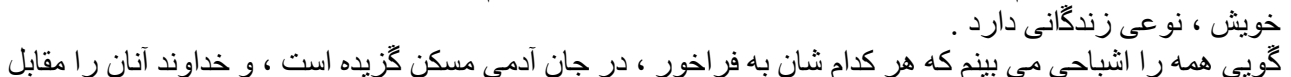

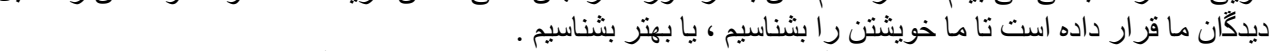

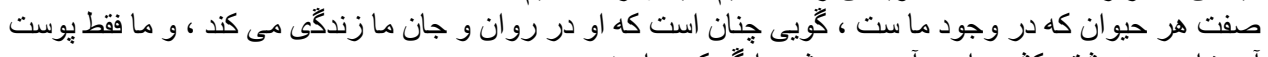

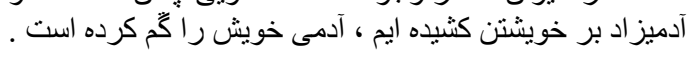


الاغتراب فى قصة "آدم" لزهرا خوش نظر دراسة تحليلية

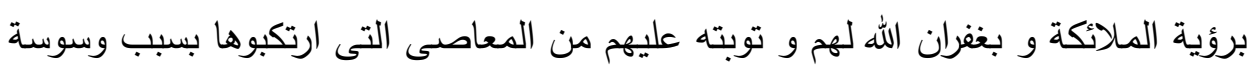
الثيطان لهم ، تقول الكاتبة :

و الله

هو الذى خلق الإنسان

$$
\text { و نفخ فيه من روحها }
$$

و زرع فى أصل ذاته فى ضمير روحه الخفى بذرة معرفته كان يعرف ما الذى سيحدث لابن آدم بعد هبوطه

حتى أن الملائكة كانوا يعلمون أيضاً

فأجابهم على اعتراضهم قائلاً :

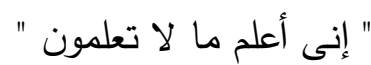

و خلق آدم خلقاً حتى أن الملائكة - أولئك المقربون للعالم القدسى - قد سجدوا لآدم بأمر

و مر على آدم ما مر

و و صار ما صنار

و هبط على الأرض لكن لم يكن وحيداً

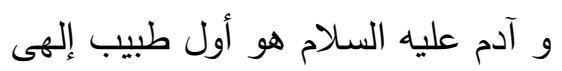

و بعده ابنه "شيث" وله الثنام

و بعده..... و و آخرون و آخرون لتئن

و تكلم نوح مع قومه ألف سنة وند وند

و حطم إبراهيم الأصنام

و شق موسى النيل حتى ينجى نفسه من فرعون الاصن

و عيسى - الذى كان يحيي الموتى و يمنح الحياة لأجسادهم الراقدة - لم يستطع أن يمنح

$$
\text { الحياة للأرواح الميتة . المين }
$$

قصة آدم هى قصة القلب لكن القلب الحى لى 
لأن القلوب الميتة هى للموتى الذين يسيرون على وجه الأرض و للمتحدثين الذين لا يعلمون شيئًا عن العلم و الحكمة و لا يفهمون كلام الأنبياء و جاء الأطباء الربانيون واحدأ بعد الآخر و تحدثوا عن السماء و عن أهلها ، تحدثوا عن آلامنا و عن العلاج لأنهم هم فقط كانوا يعرفون علاج آلام البشرية و تحدثا عن الموطن الأصلى للإنسان و جددوا ذكرى الموطن الأصلى فى قلوبنا تحدثوا عن العشق من أجلنا ، و عن معشوقتنا السماوية . و أحيوا ذكرى اليوم الأول فى قلوبنا و أينعت قلوبنا مرة أخرى و أصبحنا شباباً مرة أخرى و ألقينا نظرة جيدة إلى السماء مرة أخرى حلّقنا مرة أخرى إلى السماء كان الطيران قد فُقد من ذاكرتنا فمنحونا جناح الطيران و غسلنا الغبار من القلب فى عين ماء زلال محبتهم و أتخذت وجوهنا لوناً جديداً و تعرفت قلوبنا على الحب و تعرفت أرواحنا عليه و انبتنا بذرة المعرفة بدمع عيوننا الزلال و وصلنا إلى الربيع إلى ذى الجلال و الإكرام

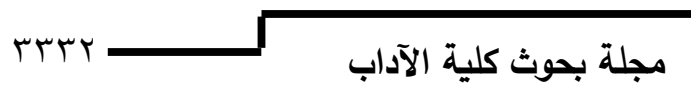


الاغتراب فى قصة "آدم" لزهر ا خوش نظر دراسة تحليلية

$$
\begin{aligned}
& \text { إلى السبوح القدوس } \\
& \text { إلى الرحمن الرحيم } \\
& \text { و ارتبطنا بالنور }
\end{aligned}
$$

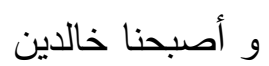

$$
\begin{aligned}
& \text { كنا قد أتينا من "إنا لله " } \\
& \text { و جعلنا وعد " إنا إليه راجعون " مضطربين } \\
& \text { وعد العودة إلى السماء } \\
& \text { وعد رؤيته جعل أرواحنا عاجزة } \\
& \text { أخضر العشق فى أرواحنا } \\
& \text { فنحن لم نكن فى الأرض بمفردنا } \\
& \text { هو كان معنا } \\
& \text { "و هو معكم أينما كنتت" } \\
& \text { تأصل عشقه فى روحنا } \\
& \text { كل من عاش بدونه سواء عاش بمرارة و شدة و سواء مات بسوء . } \\
& \text { بدونه لم يستطع الحياة } \\
& \text { لأن حياتنا منه } \\
& \text { و قلوبنا هى مكان خاص له } \\
& \text { قلب المؤمن عرش الله } \\
& \text { و الملائكة تترقب رؤيتنا } \\
& \text { و فى نفس تلك الأوقات سجدوا لنا } \\
& \text { و انتظروا حتى يسألوننا : }
\end{aligned}
$$

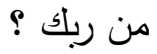

$$
\begin{aligned}
& \text { و سوف نجيبهم قائلين : }
\end{aligned}
$$




$$
\begin{aligned}
& \text { د / هاله حسن تحمه } \\
& \text { ربنا هو من أمركم بالسجود للإنسان } \\
& \text { سوف نقول لهم :- } \\
& \text { كنا نشتاق لرؤيتكم } \\
& \text { و اشتقنا أكثر لرؤية ربنا }
\end{aligned}
$$

لقد جئنا ، على الرغم من أننا تلوثنا ، و عصينا، و على الرغم من أن آلاف الظلمات قد

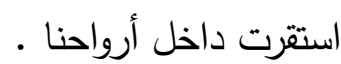$$
\text { لكن حقيبتا هى العشق • }
$$$$
\text { عشقه . ع }
$$

$$
\begin{aligned}
& \text { المجنون الذى لا يصير دون ليلى } \\
& \text { لو أننا جئنا فهو من أحضرنا } \\
& \text { و منحنا الطريق } \\
& \text { هو يحبنا } \\
& \text { لو لم يحبنا لكان تركنا } \\
& \text { و نحن عدنا } \\
& \text { هو أعادنا إليه }
\end{aligned}
$$

عشقه كان أجمل و أعمق آلاف المرات من قبل فى وجودنا و منحنا جناحأ و ريشاً للطيران.

$$
\text { و على الرغم من أننا أجبنا فى الأزل على " ألست بربكم" ؟ ب"قالوا بلى" آلى }
$$

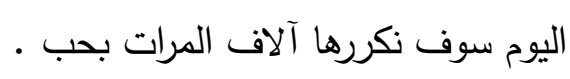

هو خالقنا .

$$
\text { هو المساعد دائماً لنا . }
$$

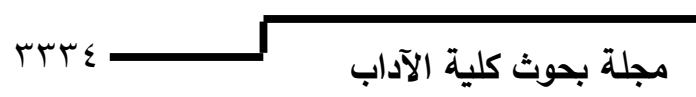




\section{الاغتراب فى قصة "آدم" لزهر ا خوش نظر دراسة تحليلية}

هو خالد ، و جعلنا خالدين لأن العشق خالد بَ .

ثم تختتم الكاتبة حديثها عن قصة آدم برسم صورة للموت تجعله أقرب ما يكون إلى

المخلص للبشر من آلامهم و غربتهم التى عانوا منها ، فقد جمعهم بموطنهم الأصلى (

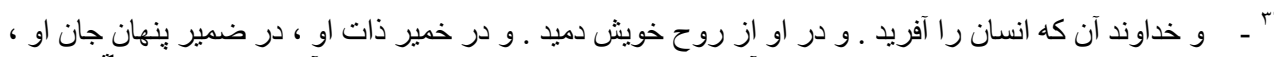

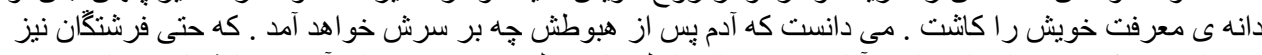

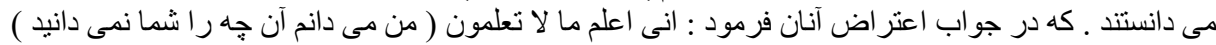

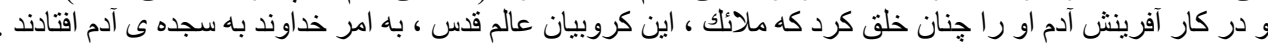

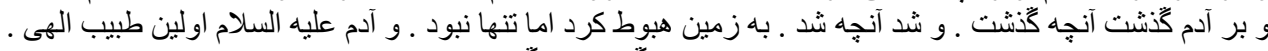

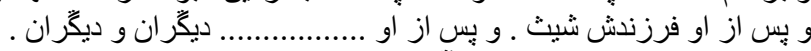

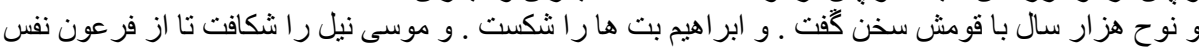

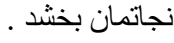
و عيسى كه مردًّان را ز نده مى كرد و به جسم خفته ى آنان جان مى بخشيد ، نتو انست جان هاى مرده را حيات بخشد

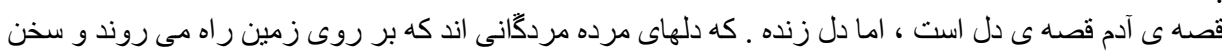

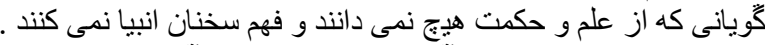

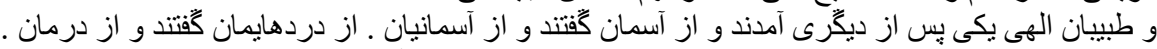

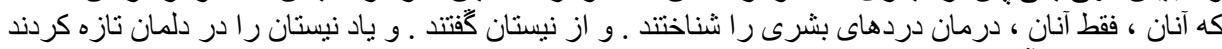

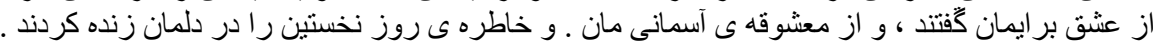

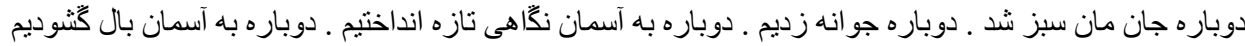

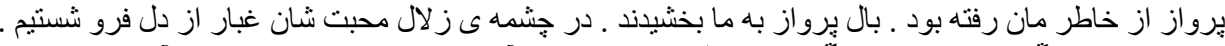

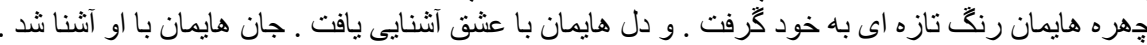

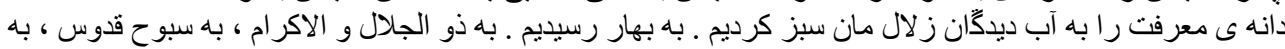

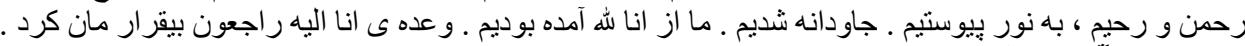

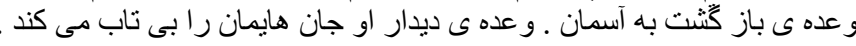

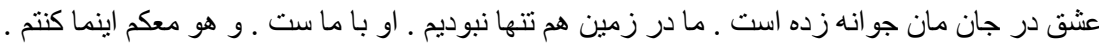

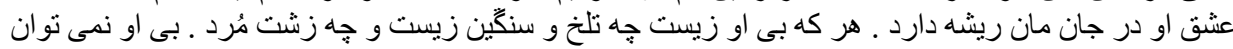

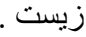

كهز زيستن ما از او ست ـ و دل هايمان جايگًاه خاص او ست ـ قلب المؤمن عرش الله ـ و باز فرشتخان جشم انتظار

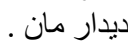
همان ها كه به ما سجده كرده بودند . منتظرند تا از ما بِّرسند : من ربك ( خداى تو كيست ؟ ) در جواب آنان خو اهيم : خدق

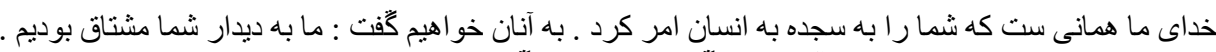

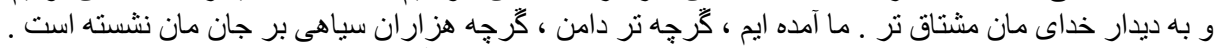

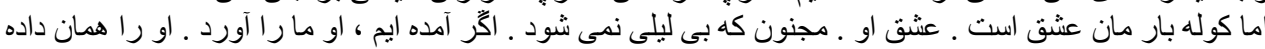

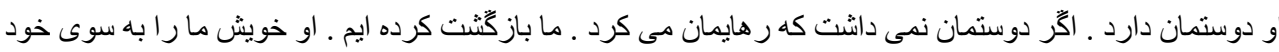

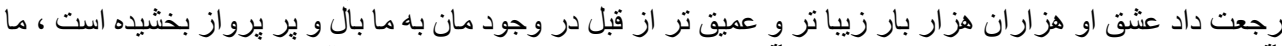

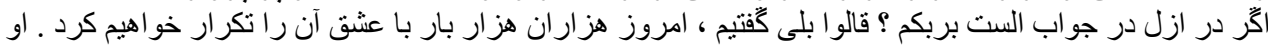

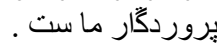

أو ياور هميشگّى ما ست ـ او در جان ما خانه دارد ـ او جاودانه است و ما را جاود دانه كرده است كه عشق جاودانه 
الجنة ) و جمعهم بالله عز وجل الذى خلقهم ، فالموت هو حياة حقيقية و ليست مزيفة كالتى

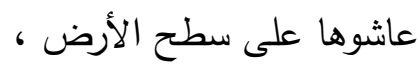
تقول الكاتبة :-

موتتا ليس سوى طيران الموت بالنسبة لنا ليس سوى التحليق نحوه

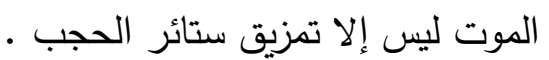

الموت هو الثوق للوصال .

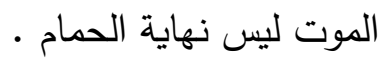

هو التحليق نحو الصديق •

الموت ليس سوى خلع لباس التراب من الجسد و التحليق نحو اللامتتاهى .

الموت ليس سوى حياة ، حياة حقيقية .

فحقيقة الحياة تكمن فى الموت .

الموت يعيش معنا لحظة بلحظة . الحسئ.

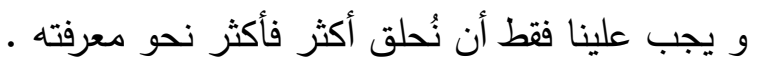

فمعرفته هى بذرة لقاء الله .

و نحن مشتاقون للقائه .

و قصة آدم

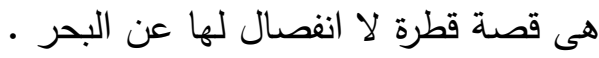

قصة إنا لله .

و قصة آدم هى قصة عودة القطرة للبحر •

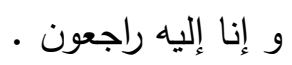

قصة آدم بدأت من كان واحداً

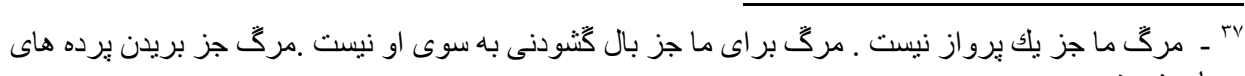

حجاب نيست . مرن

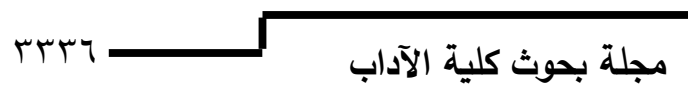


الاغتراب فى قصة "آدم" لزهرا خوش نظر دراسة تحليلية

خاتمة البحث و نتائجه

- - يعد مفهوم الاغتراب من أكثر المفاهيم إثارة للجدل و لاختلاف الآراء بين المفكرين

و الفلاسفة ، فهو من المفاهيم التى يصعب إعطاء حل قاطع فيها وتحديد معنى اهنى

شامل لها . - مان.

- الاغتراب كمفهوم إنسانى قد امتد وجوده ليشمل مختلف أوجه الحياة الاجتماعية و

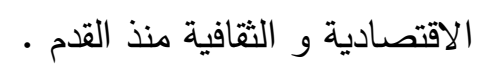

- - تمثل الاغتراب فى الإسلام فى أن الإنسان بعد ما كان واحداً مع الله صـار منفصلاً

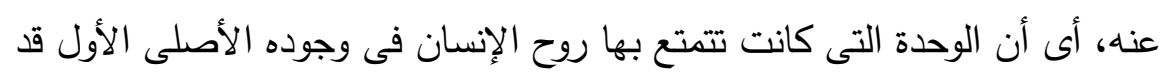

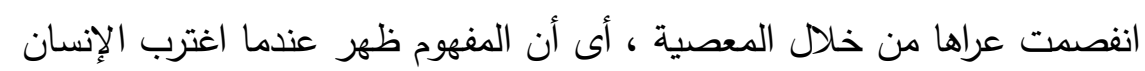

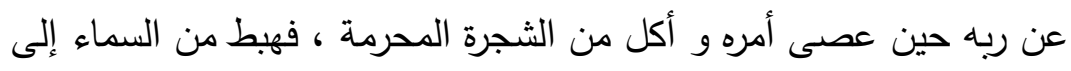

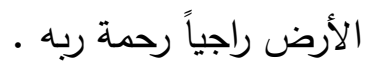

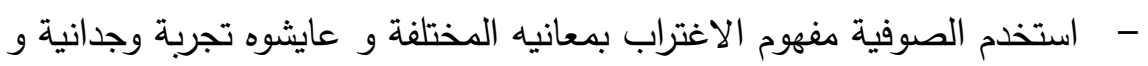

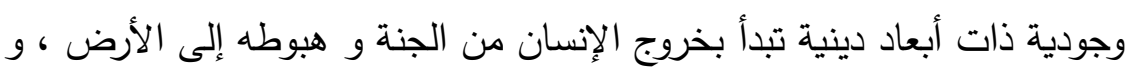

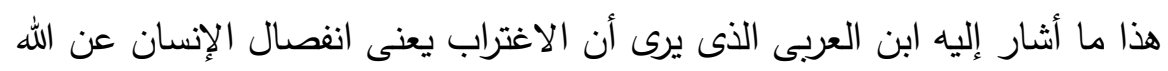

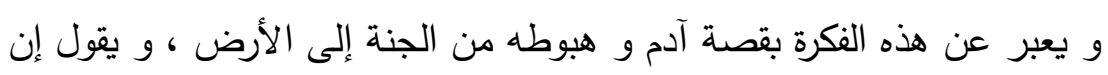

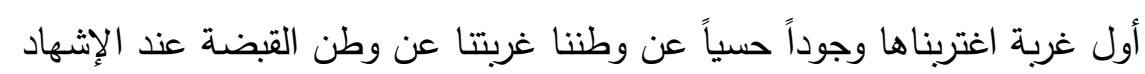
بالربوبية لله علينا و هذا الفكر هو ما اتخذته الكاتبة

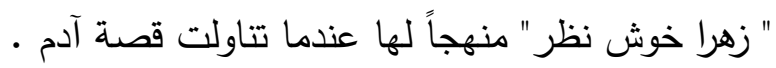

- - تساءلت الكاتبة عن مسألة خلق الإنسان و التى تمثل أحد أهم الأسئلة الوجودية

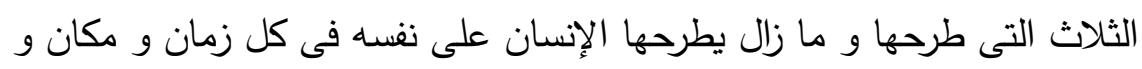

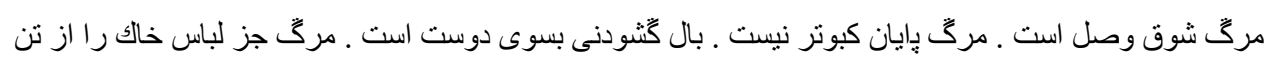

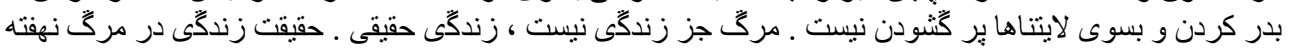

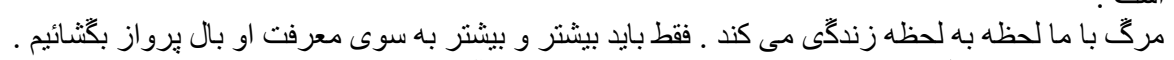

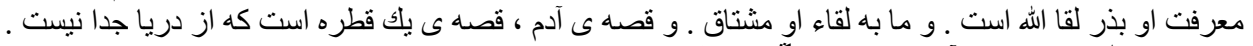

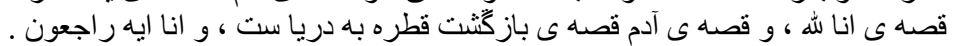

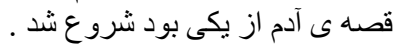


هى : من أين جاء ؟ لماذا هو موجود ؟ ما هو المصير ؟ إلا أنها قد بدأت

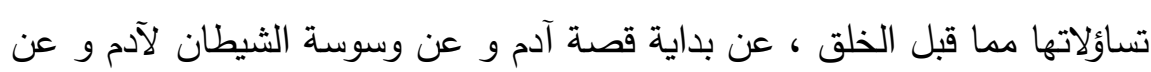

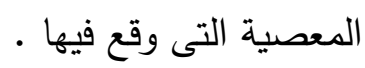
- - رأت الكاتبة أن معاناة الإنسان على الأرض هى معانهاة اغتراب عن الوطن الأصلى

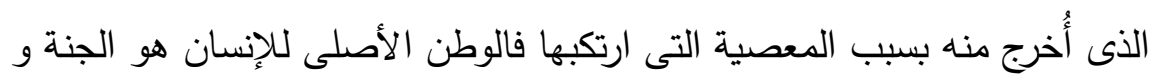

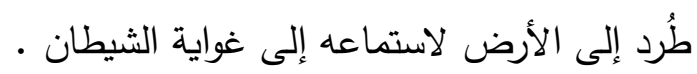

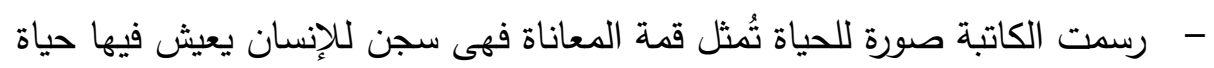

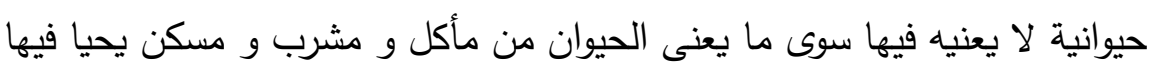

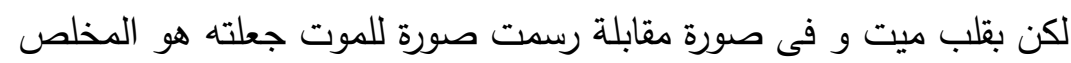

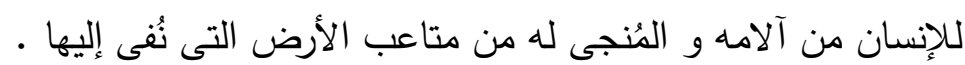
- - ترى الكاتبة أن الموت هو موت القلب و سببه هو جهل الإنسان و عدم استماعه لكلام الأنبياء و اعتزازه بعقله فقط دون سواهو هذا هو سبب أمراض الروح التى هوب هوب هون

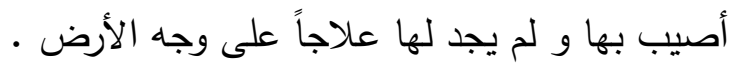
- - تعتقد الكاتبة أن الإنسان قد فقد نفسه و نسيها و أصيب بانعدام الهوية الهورية عندما هبط على الأرض و نسى الهدف من خلقه ألا و هو العبادة .

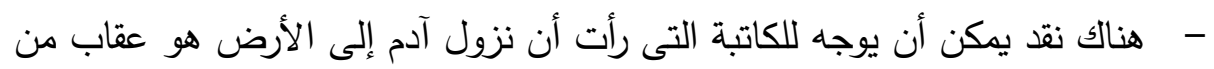

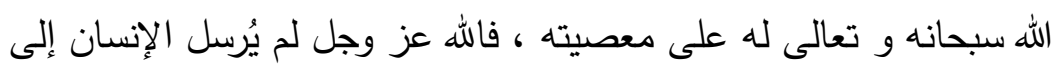

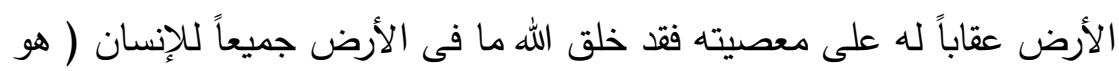

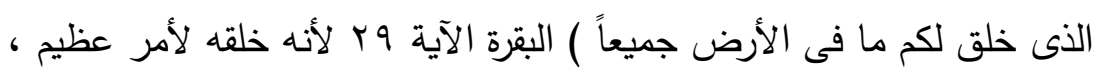

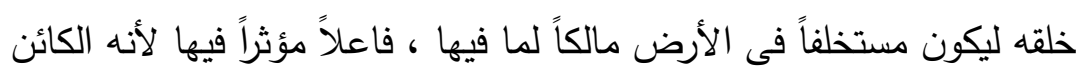
الأعلى فى هذا الكون العريض و دوره فى الأرض هو الدور الأول ، فاستخلف الله عز وجل آدم فى الأرض و منحه مقاليدها على عهد من الله و شرط و أعطاه

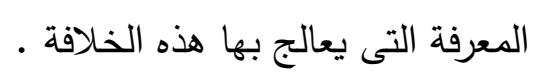

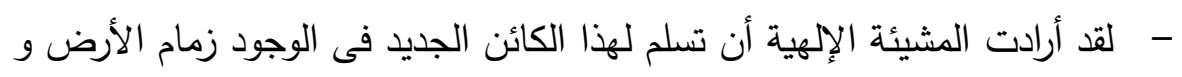
تطلق يده فيها و تكل إليه إبراز مشيئة الخالق فى الإبداع و كثف ما فى هذه إنه

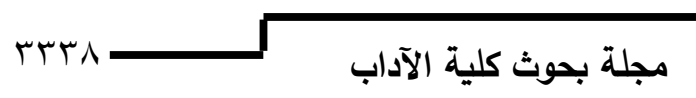


الاغتراب فى قصة "آدم" لزهرا خوش نظر دراسة تحليلية

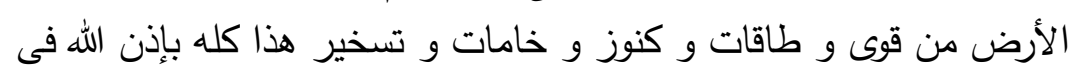

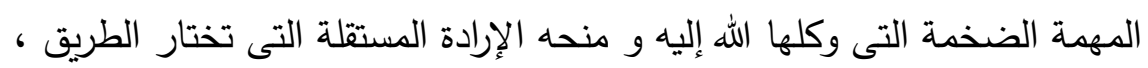

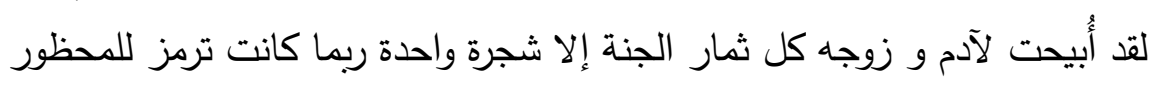

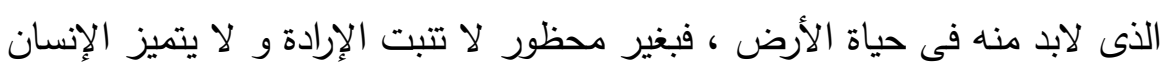

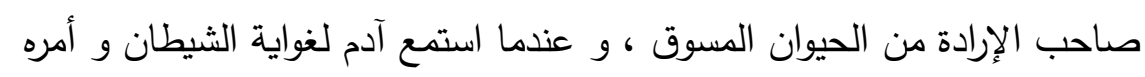

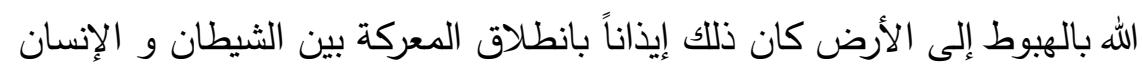

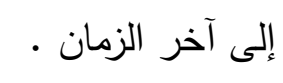

- - هناك إعلاء من شأن الإرادة فى الإنسان ، فهى مناط العهد مع الله و هى مناط

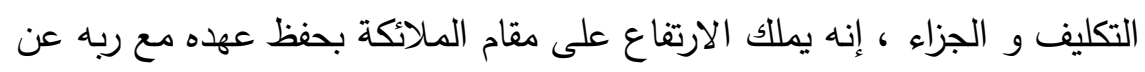

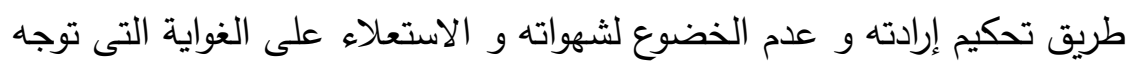

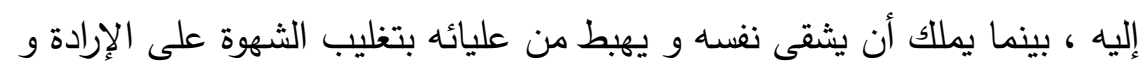

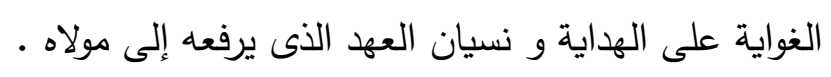

المصادر و المراجع - - الم أولا : المصدر خوش نظر : زهرا

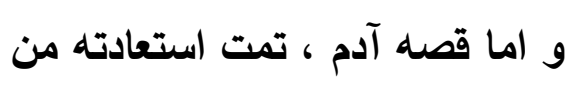
http://ketabesabz.com/book/18254 ثانياً: : المراجع ابن منظور : جمال الدين

1- لسان العرب ، مجلد · 1 ، الطبعة الأولى ، دار صبح ، لبنان ، 1971 ام .

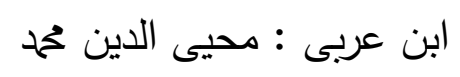

r- اصطلاحات الصوفية ، إعداد و تقديم د عبد الحميد صالح حمدان ، الطبعة

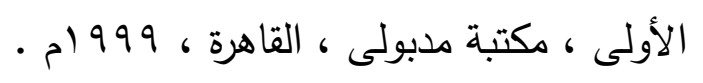


ب- الاغتراب فى الثقافة العربية ، متاهات الإنسان بين الحلم و الواقع ، مركز

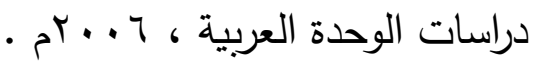

$$
\begin{aligned}
& \text { خليفة : عبد اللطيف حمح }
\end{aligned}
$$

ع - دراسات فى سيكولوجية الاغتراب ، دار غريب للطباعة و النشر و التوزيع ،

$$
\text { الحلو : الخورى يوحنا ب . . م م • }
$$

0- ترجمة اعترافات القديس أغوسطنيوس ، الطبعة الرابعة ، دار المشرق ، بيروت ،

$$
\text { - } 1991
$$

$$
\text { رجب : محمود }
$$

7- الاغتراب سيرة مصطلح، دار المعارف ، القاهرة ، 919 ام •

$$
\text { الثين : يوسف حامد }
$$

- مبادئ فلسفة هيجل ، دراسة تحليلية عن الإنسانية و الألوهية فى كتابات الشباب

، الطبعة الأولى ، جامعة قار يونس ، بنى غازى ، ع99 ام ، 9 ،

عبد الستار : لبيب

1- : قصة الخليج صر اع دائم و تفاعل مستمر ، دار المجانى ، لبنان ، 9 ، 19 م . العقيلى : عادل محمد

9- الاغتراب و علاقته بالأمن النفسى ، جامعة الرياض ، السعودية ، ع . . بم .

$$
\text { فروم : اريك }
$$

• 1 الاغتراب ، ترجمة حسن حماد ، المؤسسة الجامعية للدراسات و النشر و

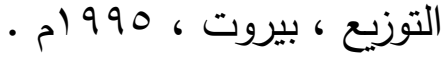

$$
\begin{aligned}
& \text { مهنا : ححمد ، خلدون معروف كان }
\end{aligned}
$$

1) - تسوية المناز عات الدولية مع در اسة لبعض مشكلات الثرق الأوسط ، مكتبة غريب ، القاهرة

$$
\text { مجلة بحوث كلية الآداب }
$$


الاغتراب فى قصة "آدم" لزهرا خوش نظر دراسة تحليلية

$$
\text { مرسى : أبو بكر }
$$

r ا- أزمة الهوية فى المراهقة و الحاجة للإرشاد النفسى ، الطبعة الأولى ، مكتبة

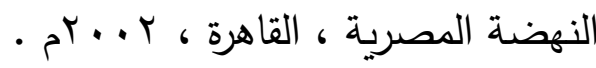

هيكل : محمد حسنين

r ا- جان جالك روسو ، حياته و كتبه ، مكتبة النهضة العربية .

ثالثاً : المجلات و الدوريات العلمية

خليفة : فتح الله

ا- الاغتراب فى الإسلام ، مجلة عالم الفكر ، الكويت ، المجلد العاشر ، العدد

$$
\text { الزغل : } 9 \text { ألول ، على و آخرون }
$$

r- الشباب و الاغتراب ، دراسة ميدانية من شمال الأردن ، مؤته للبحوث و

الدراسات ، المجلد الخامس ، ، 999

كامل : فؤاد

ץ- نظريات كارن هورنى فى التحليل النفسى ، دار المنظومة ، العدد جس ، ـ79 ام

النورى : قيس

ع - الاغتراب اصطلاحا و مفهوما و واقعا ، مجلة عالم الفكر ، الكويت ، المجلد

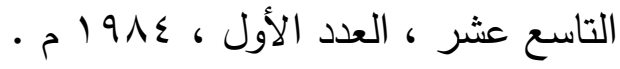

رابعاً : مواقع الثبكة الإكترونية

اكبرى : عطيه

1- عاشقانه هاى خانواده خوش نظر ، تمت استعادته من

http://www.mahaleman.ir/detail/news/6597

r- بيضايى : فاطمه 
اقتصاد مقاومتى به سبك عمو حسن و فرمانده خوش نظر ، تمت استعادته من http://sazandegi.ir/story/478

ז- توماس هابز و انسانى كه گّرَ انسان است ، تمت استعادته من https://tavaana.org/fa/Thomas_Hobbes

$$
\text { ع-الاغتراب ، الحمى : على استعادته من }
$$

http://montada.echoroukonline.com/showthread.php?t=229620

خوش نظر : حزين

ع- داونلود كتابهاى زهرا خوش نظر ، تمت استعادته من

http://ketabesabz.com/authors/2251

فروم : اريك

7- المجتمع السليم ، ترجمة محمود محمود ، تمت استعادته من

bookshttps://www.abjjad.com/author/2142568448

$$
\begin{aligned}
& \text { Vـ لماذا نفذ صبرنا ، تر جمة إبر اهيم جلانل ، تمت استعادته من } \\
& \text { https://www.abjjad.com/book/2439807316 } \\
& \text { - قصة مونتجومرى ، ترجمة داليا زيادة ، تمت استعادته من }
\end{aligned}
$$

http://daliaziada.blogspot.com.eg/2008/03/blog-post_24.html

$$
\text { حمد : على عبد المعطى }
$$

9 - سورين كيركيجارد ، مؤسس الوجودية المسيحية ، تمت استعادته من

https://www.goodreads.com/book/show/28780154

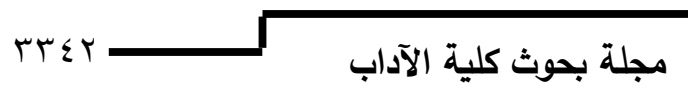


الاغتراب فى قصة "آدم" لزهرا خوش نظر دراسة تحليلية

\section{Alienation in the story of "Adam " byzahra khosh Nazar an analyticl stady}

